\title{
Comparative transcriptional profiling-based identification of raphanusanin-inducible genes
}

\author{
Moehninsi', Kenji Miura', Haruyuki Nakajyo', Kosumi Yamada' , Koji Hasegawa1,2 and Hideyuki Shigemori*1
}

\begin{abstract}
Background: Raphanusanin (Ra) is a light-induced growth inhibitor involved in the inhibition of hypocotyl growth in response to unilateral blue-light illumination in radish seedlings. Knowledge of the roles of Ra still remains elusive. To understand the roles of Ra and its functional coupling to light signalling, we constructed the Ra-induced gene library using the Suppression Subtractive Hybridisation (SSH) technique and present a comparative investigation of gene regulation in radish seedlings in response to short-term Ra and blue-light exposure.
\end{abstract}

Results: The predicted gene ontology (GO) term revealed that 55\% of the clones in the Ra-induced gene library were associated with genes involved in common defence mechanisms, including thirty four genes homologous to Arabidopsis genes implicated in R-gene-triggered resistance in the programmed cell death (PCD) pathway. Overall, the library was enriched with transporters, hydrolases, protein kinases, and signal transducers. The transcriptome analysis revealed that, among the fifty genes from various functional categories selected from 88 independent genes of the Rainduced library, 44 genes were up-regulated and 4 were down-regulated. The comparative analysis showed that, among the transcriptional profiles of 33 highly Ra-inducible genes, 25 ESTs were commonly regulated by different intensities and duration of blue-light irradiation. The transcriptional profiles, coupled with the transcriptional regulation of early blue light, have provided the functional roles of many genes expected to be involved in the light-mediated defence mechanism.

Conclusions: This study is the first comprehensive survey of transcriptional regulation in response to Ra. The results described herein suggest a link between Ra and cellular defence and light signalling, and thereby contribute to further our understanding of how Ra is involved in light-mediated mechanisms of plant defence.

\section{Background}

Raphanusanin (3-methylthio-methylene-2-pyrrolidonethione) ( $\mathrm{Ra}$ ) can be isolated from radish seedlings grown under illumination and plays a role in the light-induced inhibition of hypocotyl growth [1]. When applied unilaterally, Ra suppresses hypocotyl growth on the treated side more than on the opposite side, inducing a differential growth gradient that causes the hypocotyl to bend towards the side of application [2,3]. Blue-light irradiation rapidly decreases the 4-methylthio-3-butenyl glucosinolate (MTBG) content and abruptly increases the content of 4-methylthio-3-butenyl isothiocyanate (MTBI) and raphanusanin in the radish hypocotyls within 30 min after the onset of irradiation [4]. When MTBG,

* Correspondence: hshige@agbi.tsukuba.ac.jp

${ }^{1}$ Graduate School of Life and Environmental Sciences, University of Tsukuba, Ibaraki 305-8572, Japan

Full list of author information is available at the end of the article
MTBI, and raphanusanin at endogenous levels were applied unilaterally to etiolated hypocotyls, MTBI and raphanusanin caused hypocotyls to bend, but MTBG induced no activity. Blue-light irradiation promoted myrosinase (thioglucosidase) activity, which releases MTBI from MTBG, in hypocotyls after $10 \mathrm{~min}$, although the enzyme activity in the dark controls did not change [4]. Some chemical studies on 4-methylthio-3-butenyl isothiocyanate (MTB-ITC) have been carried out, where MTB-ITC has been spontaneously converted into raphanusanins in $\mathrm{MeOH}-\mathrm{H}_{2} \mathrm{O}$ or $\mathrm{H}_{2} \mathrm{O}$ solution [5]. The biosynthetic pathway of $\mathrm{Ra}$ is shown in Figure 1. Phototropic stimulation promotes myrosinase activity on the illuminated side of radish hypocotyls, releasing bio-active 4-methylthio-3-butenyl isothiocyanate (4-MTBI) from bio-inactive 4-methylthio-3-butenyl glucosinolate (4MTBG), and simultaneously producing bio-active Ra. Sakoda et al. demonstrated that the IAA-mediated trans- 


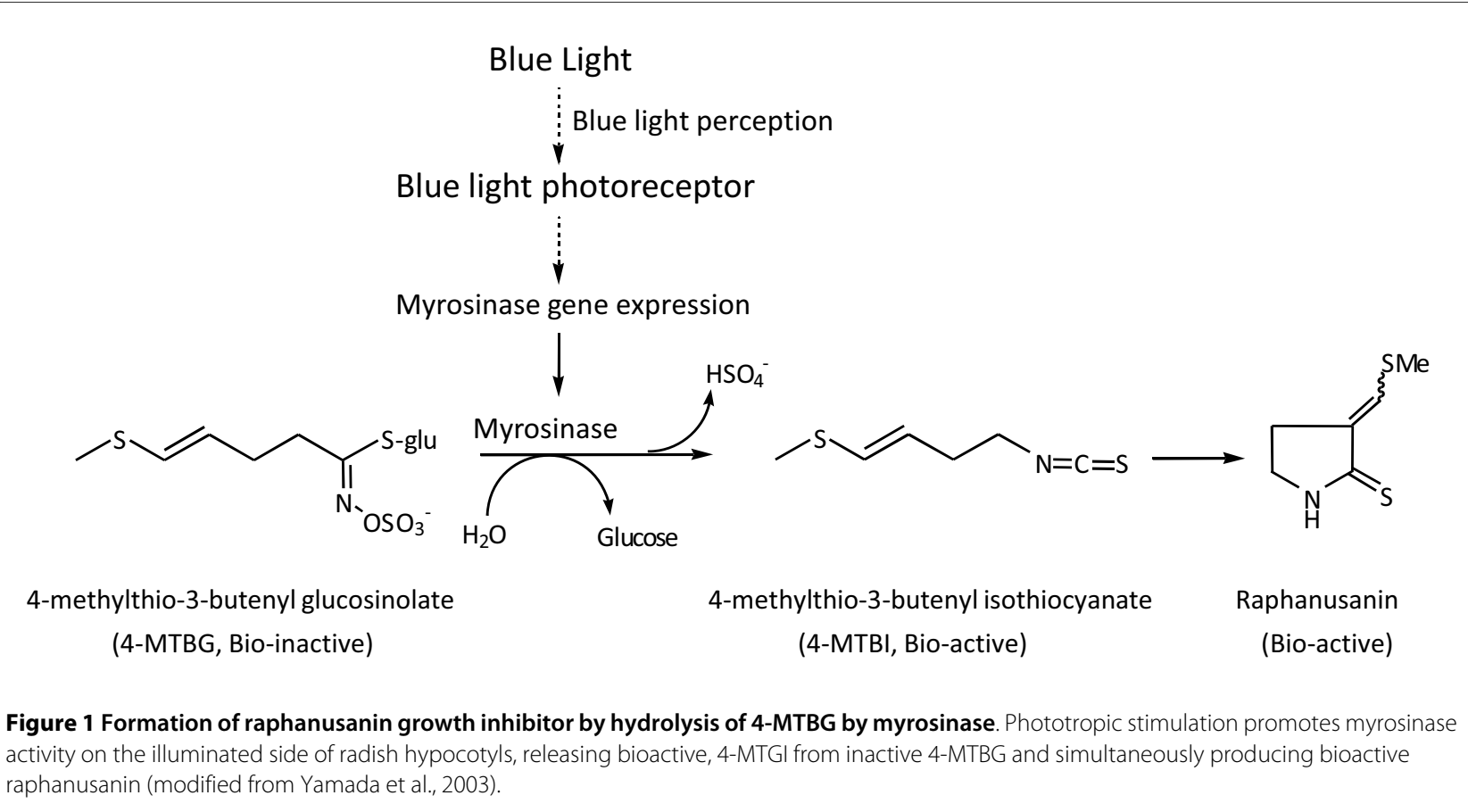

verse microtubule reorientation is significantly inhibited by the simultaneous addition of Ra analogues [6]. Moreover, Nakajima et al. showed that $\mathrm{Ra}$ inhibited apical dominance in pea seedlings [7]. There are certainly additional ways in which Ra may help a plant to adapt to the prevailing light environments, and these may be discovered through further photophysiological, cellular, biochemical, and genetic testing. We demonstrated the physiological role of $\mathrm{Ra}$ in differential growth and identified the first four genes shown to be induced by Ra using modified Differential Display RT-PCR (DD-RT-PCR). We characterised one of these genes, RsCSN3, as an essential element in the inhibition of hypocotyl growth [3]. However, our first attempt using the DD-RT-PCR method was limited to the identification of a large number of genes induced by Ra. The comprehensive understanding of the functional activity of Ra still remains elusive. To search for additional components required for the understanding of the roles of $\mathrm{Ra}$, we constructed the Ra-induced gene library using the Suppression Subtractive Hybridisation (SSH) technique. The use of a rapid and sensitive mRNA expression comparison technique (SSH) and its application in comparative studies with light will be crucial to revealing the possible roles of $\mathrm{Ra}$ and its functional coupling to light signalling. Here, we present a comparative investigation of gene regulation in radish seedlings in response to short-term $\mathrm{Ra}$ and blue-light exposure. Among the transcripts identified to be up-regulated in response to raphanusanin, we observed many genes that are related to the multiple signalling of cellular defence. This observation has allowed us to infer raphanusanin regulatory roles for a large fraction of products associated with movement, transporters, protein metabolism, protein kinases, and hydrolases.

\section{Results}

Raphanusanin-induced genes that are linked to cellular defence

To obtain Ra-induced genes, we subtracted the cDNAs in the Ra-untreated four-day-old radish seedlings from those in the samples treated with $\mathrm{Ra}$ (approximate endogenous level, $50 \mathrm{ng}$ ) $15 \mathrm{~min}$ (see additional file 1). Starting with two micrograms of poly-A+ RNA prepared from Ratreated samples, 287 cDNA clones induced by Ra were obtained (Table 1). The nucleotide sequences of all of the clones were determined by sequencing the inserts from both ends, altogether generating 574 ESTs $(287 \times 2=574$; Table 1). The Ra-induced cDNA library digested with RsaI contained on average $400 \mathrm{bp}$ inserts. Thus, the sequences from both ends were overlapping. All of the sequences were then assembled by the Phrap program (Codon Code Aligner Sequence Assembler v3.0.1) and classified into 101 non-redundant forms after building the contigs (Table 1). All of the 101 non-redundant sequences were submitted to the DDBJ database with accession numbers assigned (see additional file 2). The sequence of each non-redundant EST was identified by similarity search in the NCBI non-redundant public sequence database (nr) [8]. If a gene contained the RsaI digestion site, two cDNA clones could be identified. Therefore, neighbouring clones were joined by alignment with subject sequences obtained by a BLAST search. 
Table 1: Summary of the structural analysis of the raphanusanin-induced CDNA library

\begin{tabular}{lc}
\hline Category & Number of sequences \\
\hline Redundancy consideration & \\
Clones & 287 \\
Sequenced & 574 \\
Non-redundant sequence & 101 \\
Independent gene & 88 \\
Ra-induced genes with & \\
high similarity against & \\
BLASTX & \\
Arabidopsis thaliana EST & 77 \\
Raphanus sativus EST & 3 \\
Brassica napus EST & 4 \\
Brassica oleracea EST & 1 \\
Gallus gallus EST & 1 \\
Novel EST & 2 \\
\hline
\end{tabular}

After the BLAST search, 88 Ra-induced independent genes were identified, and 13 were duplicates. Of the 88 independent genes, 77 were demonstrated to have significant homology with Arabidopsis thaliana genes, 9 were homologous with other organisms such as Brassica and chicken, and 2 were novel ESTs (Table 1). The 88 independent genes were classified into three physiological associations or ten biochemical functional categories based on the best BLASTX match of the corresponding ESTs against NCBI non-redundant protein database (expect value $<0.01$ ) or TAIR Arabidopsis protein database (Figure 2 and see additional file 2).

Forty-eight of the $88 \mathrm{Ra}$-inducible genes (55\%) were categorised as related to cellular defence, and 7 genes (8\%) were categorised as related to energy metabolism (Figure 2A). On the other hand, 33 of the $88 \mathrm{Ra}$-inducible genes (37\%) could not be assigned to any physiological category (Figure $2 \mathrm{~A}$ and see additional file 2 ). A high portion of these genes are involved in common defence mechanisms, including CIPK1, PTI1, GTF, RPK (ERECTA), HSP90, MBP1, CAMTA3, ACC oxidase (ACCO), GTPase, UBQ, DRP, PLC, and PLD [9-18]. Furthermore, nine genes function in the response to abiotic stress, including USP, SDR, RALF 23, and GASA4 [1922]. There were also five genes known to be involved in toxic catabolic processes and in the response to oxidative stress, such as catalase 2 (CAT2), peroxidase, NTRA, and MetE [23-25]. In addition, two genes, pescadillo and coproporphyrinogen III oxidase (CPOX), are induced by DNA damage and protein lesions [26,27].

Based on biochemical classification (Figure 2B and see additional file 3), 31 genes among the $88 \mathrm{Ra}$-inducible genes were categorised as signalling-related, such as kinases (10 genes, $12 \%)$, protein metabolism/binding (11 genes, $13 \%$ ), and signal transduction (10 genes, $12 \%)$. The leucine-rich repeat (LRR) disease-resistance protein kinases, serine/threonine, and tyrosine protein kinases, such as CIPK1, PKC, MAK, and Ptil, were included in the kinase category. Six genes involved in the ubiquitinproteasome pathway, such as CSN3, KEG, CUL1, UMP1, UBQ3, and RING finger [11,28-32], were categorised into protein metabolism. In addition, the nine genes involved in signal transduction are all known to be associated with defence against environmental stress (e.g., PLC, PLD, DRP, and ERECTA). Other than the genes involved in housekeeping functions, those associated with signal transduction, kinases, movement and transporter, and hydrolase were the most abundant (Figure 2B and see additional file 3). These results indicate that $\mathrm{Ra}$ induces changes in the genetic network in preparation for a distinct phase of cellular communication. In addition, a bioinformatic analysis revealed that 34 genes among the 88 Ra-induced genes homologous to Arabidopsis genes were implicated in the function of the R-gene-triggered resistance in programmed cell death (PCD), as shown in Table 2.

\section{The determination of reference genes for qRT-PCR}

In order to evaluate transcriptional regulation, the selection of the most appropriate and stable housekeeping gene as a control is necessary. The information for choosing the proper housekeeping gene in the radish system is still limited. Therefore, the transcript levels of seven housekeeping genes commonly used in plant gene expression analysis, actin8, ubiquitin3, $18 \mathrm{~S}$ rRNA, tubulin $\alpha-6$, rRNA protein (L4), initiation factor 2 (eIf2), and elongation factor $1 \mathrm{~B}$-alpha (ef1 $\alpha$ ), were measured before and after the Ra treatment (see additional file 4). The entire experiment was performed in triplicate, and the results were combined for statistical analysis. The cycle threshold $\left(C_{\mathrm{T}}\right)$ of each transcript was compared. Tubulin $\alpha-6$ was the most abundant (lowest $C_{T}$ ) transcript and L4 was the least abundant (see additional file 4 and additional file 5). The ANOVA F-test of differences among time points after Ra treatment indicated that the transcript levels of three genes, ef1 $\alpha$, elf2, and L4, were not significantly altered before and after Ra treatment in radish seedlings. Two of these three genes, ef $1 \alpha$ and eIf 2 , had a small coefficient of variation (CV) (see additional file 5). Both consistency across time points (low slope) and high predictability (low CV) are desired for a control. The stability index was calculated based on the product of the slope and the CV (see additional file 5). The gene with the lowest stability index provides the best control. In this study, ef1 $\alpha$ had the lowest stability index and elf2 had the second lowest as evidenced by their low slope and CV. 


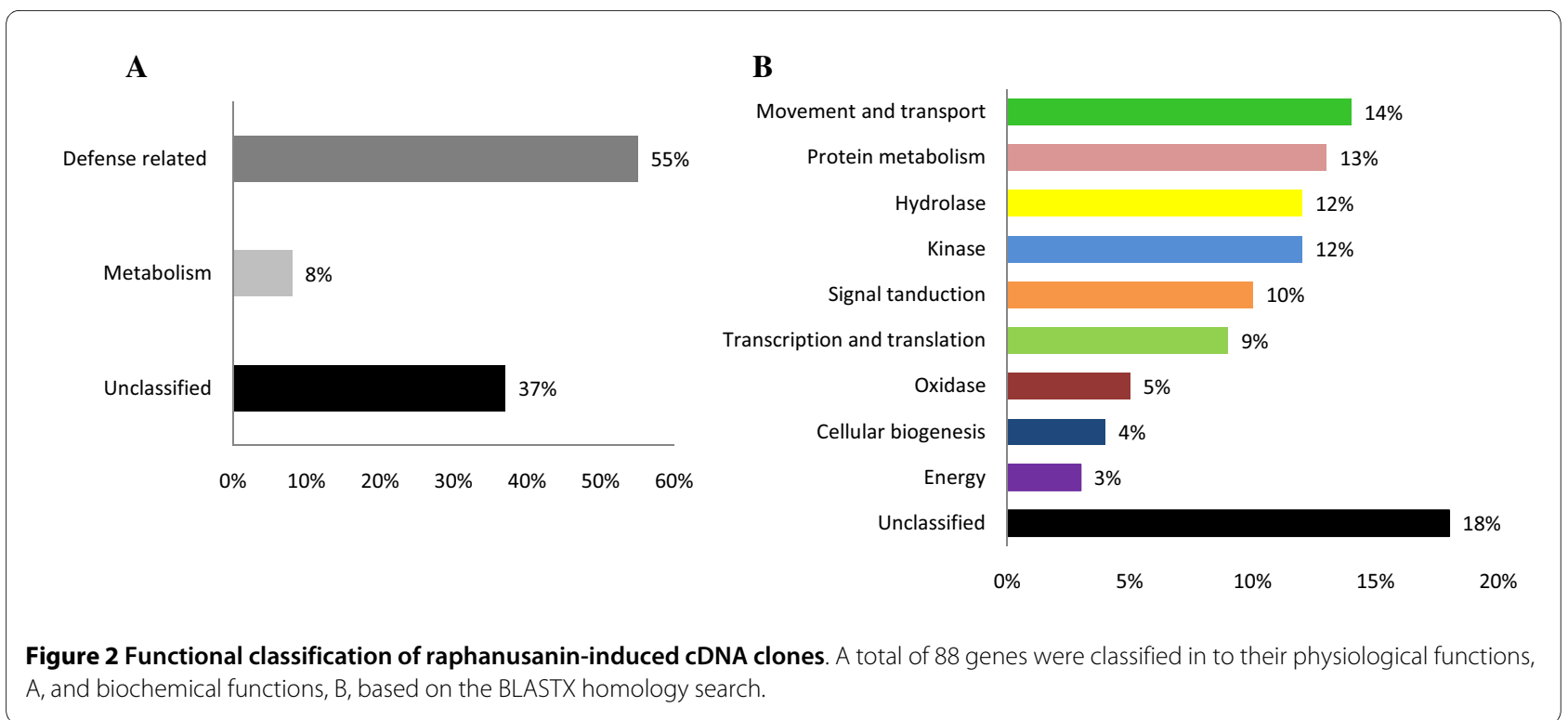

Therefore, ef $1 \alpha$ and eIf 2 were used to normalise the expression levels of the genes of interest.

\section{Defence-related genes are positively regulated in response to raphanusanin}

Fifty expressed sequence tags (ESTs) from various functional categories were selected from among the 88 independent genes from the Ra-induced library to confirm the induction of transcripts by quantitative RT-PCR. Three independent preparations of mRNA for each biological replicate were pooled to eliminate inconsistencies due to sampling. Three independent experiments were carried out from three independent pools. An analysis of the genes exhibiting changes in expression greater than 1.5 -fold or less than 0.6 -fold at both time points $(15 \mathrm{~min}$ and/or $30 \mathrm{~min}$ ) in comparison to the untreated samples revealed that 44 genes were up-regulated and 4 were down-regulated (Table 3 and Figure 3). Some genes were highly expressed during the first $15 \mathrm{~min}$, while others were more pronounced at $30 \mathrm{~min}$. An analysis of genes with assigned functional categories revealed that several metabolic processes linked to common protective functions, including the biosynthesis of stress-activated hormones, reactive oxygen scavenging enzymes, signal transducers, and components of the protein degradation system, were up-regulated (Table 3). The number of upregulated genes and the expression levels were substantially greater at $15 \mathrm{~min}$ than at $30 \mathrm{~min}$ (Figure 3 ). This difference could be attributed to the early activation of genes underlying the mechanistic response to Ra. Among the down-regulated genes, the transcript levels of RMB1 and RMB2 were lower at $15 \mathrm{~min}$, whereas those of CND41 and PKC were lower at $30 \mathrm{~min}$. The highly expressed genes, NTRA $(>70)$ and peroxidase $(>5)$, are reactive oxygen-scavenging enzymes involved in the removal of superoxide radicals [33,34]. In addition, DRP, ERECTA $(>10)$, and CAMTA $3(>3)$ are signal transducers that rescue cells from pathogenic attacks [35-37]. Two genes, ACCO and MBP1 $(>10)$, encode the genes involved in induction of the major defence-related hormones, ethylene and jasmonate acid, respectively [38,39]. It should be noted that seven genes (UBQ3, PMF1, CUL1, CSN3, KEG, and $\mathrm{C}_{3} \mathrm{HC}_{4}$-type Ring Finger, HSP90) involved in the proteolytic pathway were up-regulated in response to $\mathrm{Ra}$. These genes are implicated in the regulation of a vast array of biological processes, including the cell cycle [40], apoptosis [41], the adaptive immune system [42], plant growth regulation [43,44], and responses to oxidative stress $[45,46]$. The most highly expressed genes were defence-associated genes, implicating the correlation of Ra with cellular defence.

\section{Raphanusanin is functionally coupled with the early blue- light response}

Because Ra is a blue light (BL)-induced growth inhibitor of radish seedlings [3], elucidating the relationship between $\mathrm{Ra}$ and blue light is a crucial step in understanding the proper roles of Ra. To obtain information regarding the strict specificity of the Ra involvement in the early light-mediated development, four-day-old etiolated radish seedlings were irradiated with three different kinds of BL fluences. The transcriptional profiles of 33 highly Rainducible genes were analysed in response to BL. The 25 ESTs were commonly regulated by the different intensities and durations of BL irradiation (Figure 4). Many stress-related genes (e.g., CUL1, CSN3, and MBP1) were observed to respond early during the first five minutes of high-fluence pulses, while they increased dramatically over time in the continuous light of low fluence, poten- 
Table 2: Annotation of Ra-induced genes homologous to Arabidopsis genes that are involved in R-gene-triggered resistance in PCD pathway

\begin{tabular}{|c|c|c|c|}
\hline Gene family & No. of gene & Putative function & Reference \\
\hline Protein kinase & & $\begin{array}{l}\mathrm{R} \text { proteins as regulatory adaptors } \\
\text { in plant apotosomes }\end{array}$ & \\
\hline Leucine Rich Repeat transmembrane protein & 4 & & $\begin{array}{l}\text { Torres et al. (2006); Hofius et al. } \\
(2007)[56,47]\end{array}$ \\
\hline Serine-theorine protein kinases (CIPK1, Pit1, Mak) & 3 & & $\begin{array}{l}\text { Schwachtje et al. (2006); Hofius et } \\
\text { al. }(2007)[16,47]\end{array}$ \\
\hline Receptor-like kinase (ERECTA) & 1 & & Chen et al. (2003) [49] \\
\hline Glycoprotein & 1 & & Wycoff et al. (1995) [48] \\
\hline Oxidative \& electrophilic stress & 3 & $\begin{array}{l}\text { Signal activators in tranduction } \\
\text { network of HR-related PCD }\end{array}$ & $\begin{array}{l}\text { Zhang and Kirkham (1994); Arner } \\
\text { and Holmgren (2000); Laloi et al. } \\
\text { (2001); Heinemann et al. (2008); } \\
\text { Zhu et al. (2008) }[60,57,58,34,66]\end{array}$ \\
\hline \multicolumn{4}{|l|}{ NTRA,CAT2, Peroxidase } \\
\hline Channel activators & 4 & & $\begin{array}{l}\text { Gelli et al. (1997); Nurnberger et al. } \\
\text { (2004); Zimmermann et al. (1997); } \\
\text { Galon et al. (2008) }[52,51,53,37]\end{array}$ \\
\hline \multicolumn{4}{|l|}{ CAMTA3, KT, POT, $\mathrm{H}^{+}$ATPase } \\
\hline Lignin-associated genes & 3 & & \\
\hline DRP, Peroxidase , RALF23 & & & $\begin{array}{l}\text { Franssen and Bisseling (2001); } \\
\text { Pearce et al. (2001); Navarro et al. } \\
(2004)[19,84,35]\end{array}$ \\
\hline GTPases & 2 & & \\
\hline (Rab-like small GTPase, FfG SRP GTPase) & & & $\begin{array}{l}\text { Ono et al. (2001); Cheung et al. } \\
(2008)[110,111]\end{array}$ \\
\hline Chloroplast target gene & 1 & & \\
\hline CPOX & & & Ishigawa (2005) [27] \\
\hline Ubiquitin-proteosome system & 7 & $\begin{array}{l}\text { Modulators of R-gene-triggered } \\
\text { resistance }\end{array}$ & $\begin{array}{l}\text { Zou et al. (2006); Liu et al. (2002); } \\
\text { Shirasu et al. (2003); Ren et al. } \\
\text { (2005); Stone et al. (2006); } \\
\text { Kawasaki et al. (2005); Taupp et al. } \\
\text { (2008). [9,28,67,71,30,70,32] }\end{array}$ \\
\hline \multicolumn{4}{|c|}{$\begin{array}{l}\text { HSP90, CSN3, CUL1, KEG, C3HC4-type Ring Finger, UBQ3, } \\
\text { PMF1 }\end{array}$} \\
\hline Stress responsive hormones & 3 & $\begin{array}{l}\text { R-gene function in hormonal } \\
\text { control of PCD activation }\end{array}$ & $\begin{array}{l}\text { Ohtsubo et al. (1999); Ciardi et al. } \\
\text { (2001); Desikan et al. (2001); Kim } \\
\text { et al. (2003); Hudgins et al. (2004) } \\
{[73,74,77,38,12]}\end{array}$ \\
\hline \multicolumn{4}{|l|}{ ACC oxidase, MBP1, CAMTA3 } \\
\hline Phosphatidic acid precursors & 2 & $\begin{array}{l}\text { Modulators of lipid-based signals } \\
\text { in PCD }\end{array}$ & $\begin{array}{l}\text { Smith et al. (2004); Chen et al., } \\
\text { 2007; Ramina et al. (2007) } \\
{[42,49,18]}\end{array}$ \\
\hline PLC, PLD & & & \\
\hline
\end{tabular}


Table 3: Annotation of up- and down-regulated genes in the Ra+-Ra- library

\begin{tabular}{|c|c|c|c|c|}
\hline \multirow[t]{2}{*}{ Familya } & \multirow[t]{2}{*}{ Genome initiative No. and Putative function } & \multicolumn{2}{|c|}{ Expression ratio } & \multirow[t]{2}{*}{ Function $\mathrm{b}$} \\
\hline & & $15 \mathrm{~min}$ & $30 \mathrm{~min}$ & \\
\hline NTRA & AT2G17420 NTRA (NADPH-dependent thioredoxin reductase 2) & $74.3 \pm 11.2 *$ & $4.18 \pm 1.9$ & 1 \\
\hline DRP & AT4G23690 Disease resistence response protein (DRP) & $33.7 \pm 6.4^{*}$ & $9.65 \pm 2 *$ & 2 \\
\hline ERECTA & ATG26330 Receptor Protein kinase ERECTA (ER) & $10.88 \pm 2.3^{*}$ & $15.82 \pm 1^{*}$ & 2 \\
\hline CCR4-NOT & AT3G44260 CCR4-NOT transcription complex protein & $4.86 \pm 0.4^{*}$ & $3.4 \pm 0.2^{*}$ & 3 \\
\hline CSN3 & AB-355980 cop9 signalosome subunit 3 & $4.2 \pm 0.7^{*}$ & $1.5 \pm 0.3$ & 4 \\
\hline Kinesin & AT2G21380 kinesin motor-protein-related & $3.93 \pm 0.8^{*}$ & $3.97 \pm 1$ & 5 \\
\hline UMP1 & AT1G67250 Proteasome maturation factor UMP1 & $3.9 \pm 0.6 *$ & $3 \pm 0.4^{*}$ & 4 \\
\hline ACCO & X81628.1 ACC oxidase & $3.67 \pm 0.2 *$ & $3.96 \pm 1.4$ & 1 \\
\hline USP & AT3G53990 Universal stress protein (USP) family protein & $1.93 \pm 0.2 *$ & $2.02 \pm 0.6$ & 2 \\
\hline MBP 1 & Y11482 Myrosinase binding protein MBP1 & $3.6 \pm 0.5$ & $5.1 \pm 0.8^{*}$ & 4 \\
\hline KT & AT4G19960 potassium iron transporter (KT) & $3.4 \pm 0.9$ & $2.24 \pm 0.4^{*}$ & 5 \\
\hline САMTA 3 & AT2G22300 Calmodulin-binding transcription activator 3 (CAMTA 3) & $1.65 \pm 0.2$ & $2.03 \pm 0.1^{*}$ & 3 \\
\hline PTI1 & AT2G30740 PTI1-like protein tyrosine kinase & $2.18 \pm 0.2^{*}$ & $3.12 \pm 0.6$ & 6 \\
\hline CUL1 & AT4G02570 Cullin-like protein, a subunit of E3 ubiquitin ligase & $2.83 \pm 0.4$ & $1.86 \pm 0.2$ & 4 \\
\hline SDR & AT4G09750 short-chain dehydrogenase & $2.37 \pm 0.3$ & $2.2 \pm 0.0 .4$ & 7 \\
\hline Peroxidase & AT3G32980 Heme-dependent peroxidase & $5.5 \pm 0.5 *$ & $3.43 \pm 0.3^{*}$ & 1 \\
\hline HSP90 & AT4G24190 SHD (SHEPHERD) HSP90 & $1.38 \pm 0.3$ & $1.26 \pm 0.1$ & 4 \\
\hline KEG & AT5G13530 RING E3 ligase protein (KEG) & $2.13 \pm 0.1 *$ & $0.8 \pm 0.1$ & 4 \\
\hline CIPKI & AT2G30360 SNF 1-related protein kinase & $2.19 \pm 0.4$ & $2.9 \pm 0.38^{*}$ & 6 \\
\hline $\mathrm{GH} 3$ & AT5G20950 Glycosyl hydrolase family 3 protein(GH3) & $2.1 \pm 0.3$ & $1.4 \pm 0.1$ & 7 \\
\hline CESA5 & AT5G09870 Cellulose synthase 5 - transferase & $1.5 \pm 0.1$ & $1.95 \pm 0.1 *$ & 5 \\
\hline CAT2 & AF139538 Catalase2 & $1.97 \pm 0.2^{*}$ & $1.6 \pm 0.3$ & 1 \\
\hline Glycoprotein & AT1G14710 Hydroxy proline rich glycoprotein family & $1.88 \pm 0.2^{*}$ & $0.9 \pm 0.1$ & 10 \\
\hline РОТ & AT3G16180 Proton-dependent oligopeptide transport (POT) family protein & $1.82 \pm 0.1 *$ & $1.05 \pm 0.1$ & 5 \\
\hline LRT & AT2G31880 Leucine-rich repeat tranmemberane protein kinase & $1.91 \pm 0.5$ & $1.7 \pm 0.2$ & 6 \\
\hline Clathrin & AT1G60780 Clathrin adaptor complexs medium subunit family protein & $1.8 \pm 0.14^{*}$ & $1.2 \pm 0.1$ & 5 \\
\hline PKC & AY835401.1 Protein Kinase C conserved region 2 & $1.7 \pm 0.2$ & $0.38 \pm 0.1 *$ & 6 \\
\hline Pescadillo & AT5G14520 Pescadillo-related protein & $1.7 \pm 0.2$ & $2.12 \pm 0.4$ & 3 \\
\hline $3 \mathrm{KCS} 4$ & AT1G19440 Very long-chain fatty acid condensing enzyme & $1.6 \pm 0.1$ & $1.5 \pm 0.2$ & 5 \\
\hline Profilin & AT2G19760 Profilin1 & $1.59 \pm 0.1$ & $2.23 \pm 0.1 *$ & 9 \\
\hline Dehydrin & AT2G39750 Dehydration-responsive family protein & $1.67 \pm 0.2$ & $1.8 \pm 0.3$ & 10 \\
\hline$P G \beta 1$ & AT1G70370 Polygalacturonase isoenzyme 1 beta subunit homolog & $1.56 \pm 0.2$ & $1.44 \pm 0.2$ & 10 \\
\hline MAK & AT5G45430 serine/threonine-protein kinase Mak & $1.6 \pm 0.3$ & $1.25 \pm 0.1$ & 6 \\
\hline 3PGDH & AT1G17745 3-phosphoglycerate dehydrogenase & $1.65 \pm 0.1 *$ & $1.8 \pm 0.2$ & 7 \\
\hline Ring Finger & AT3G09760 C3HC4-type Ring Finger & $1.55 \pm 0.2$ & $1.92 \pm 0.1^{*}$ & 4 \\
\hline G6PDH & AT5G35790 Glucose 6 -phosphate dehydrogenase & $0.69 \pm 0.1$ & $1.6 \pm 0.2$ & 7 \\
\hline GTPase & AT5G53570 Gtpase activator protein for Rab-like GTPase-like protein & $1.5 \pm 0.1$ & $2 \pm 0.2$ & 2 \\
\hline UBQ3 & At5g03240 UBQ3 & $1.4 \pm 0.1$ & $2.35 \pm 0.2 *$ & 4 \\
\hline CND41 & AT3G18490 aspartyl protease family protein & $1.3 \pm 0.1$ & $0.01 \pm 0.1 *$ & 4 \\
\hline MetE & AT5G17920 Cobalamin-independent methionine synthase & $1.4 \pm 0.1$ & $1.13 \pm 0.1$ & 4 \\
\hline RALF & AT3G16570 Rapid Alkalization Factor 23 (RALF23) & $1.31 \pm 0.2$ & $2.3 \pm 0.4$ & 2 \\
\hline PPEase & AT2G26870 Phosphoesterase family protein & $1.3 \pm 0.1$ & $1.3 \pm 0.1$ & 7 \\
\hline CPOX & AF375424 Coproporphyrinogen III oxidase & $1.3 \pm 0.1$ & $1.45 \pm 0.1$ & 1 \\
\hline BURP & AT1G70370 Polygalacturonase isoenzyme 1 beta subunit homolog & $1.3 \pm 0.1$ & $1.1 \pm 0.1$ & 10 \\
\hline
\end{tabular}


Table 3: Annotation of up- and down-regulated genes in the Ra+-Ra- library (Continued)

\begin{tabular}{|c|c|c|c|c|}
\hline GASA4 & AT5G15230 GASA4 (GAST1 protein homolog) & $1.27 \pm 0.2$ & $3.1 \pm 0.7$ & 10 \\
\hline PLC & AAD26119.1 Phosphoinositide- specific phospholipase C & $1.23 \pm 0.1$ & $1.78 \pm 0.2$ & 2 \\
\hline MAG2 & AT3G47700 MAG2(chromosome structure maintenance protein-related) & $1.2 \pm 0.1$ & $1.7 \pm 0.1 *$ & 5 \\
\hline GTF & AT1G19710 Glycosyl transferase family 1 protein & $1.07 \pm 0.1$ & $1.95 \pm 0.1^{*}$ & 5 \\
\hline RMB2 & AB042187 Myrosinase (RMB2) & $0.45 \pm 0.1$ & $1.66 \pm 0.1^{*}$ & 7 \\
\hline RMB1 & AB04218 Myrosinase (RMB1) & $0.52 \pm 0.1$ & $1.52 \pm 0.2$ & 7 \\
\hline
\end{tabular}

${ }^{\mathrm{a}}$ one representative clone for each gene is shown. Three independent biological replicates were performed. Value \pm s.e. indicates expression ratio of Treatment/Control after normalization \pm standard error of the mean $(n=3)$.Genes in the table are listed in decreasing expression ratios according to genes in the Ra+-Ra- library. Genes that differ significantly (student $t$ test $\mathrm{p}$-value less than 0.05 ) in their expression between the treatment and control are marked with an asterisk $(*)$. Bold represents the expression ratios $(\geq 1.5$ or $\leq 0.6)$. bThe functional categories are, 1 : Oxidase, 2: signal tranduction, 3: transcription and translation, 4: protein metabolism/binding, 5: movement and transport, 6: kinases, 7: Hydrolases, 8: Energy, 9: Cellular biogenesis, 10: Unclassified. The values shown represent fold change (treatment vs. control).

tially resulting from the reciprocity of the dose response (Table 4). Two genes (PKC and SDR) were specific to the continuous-light response, and three genes (PLC, USP, and 3KCS4-21) were specific to the pulsed-light response. There were also a few genes regulated by Ra and BL in the opposite manners (e.g., RMB2, and CAT). The observed responses for different fluences reveal that the range of fluences over which the response specificities to continuous or pulsed light may be attributed to the action of phot1 at lower fluence rates $\left(0.1-50 \mu \mathrm{mol} \mathrm{m} \mathrm{m}^{2} \mathrm{~s}^{-1}\right)$ and phot2 at higher fluence rates $\left(1-250 \mu \mathrm{mol} \mathrm{m}^{2} \mathrm{~s}^{-1}\right)$. Several genes involved in growth inhibition were up-regulated by $\mathrm{Ra}$ and BL (Figure 4 and Table 4). To validate, the expression levels of seven genes participating in growth inhibition were measured by semi-quantitative RT-PCR analysis (Figure 5). These results suggest that blue light facilitates the expression of Ra-inducible genes.

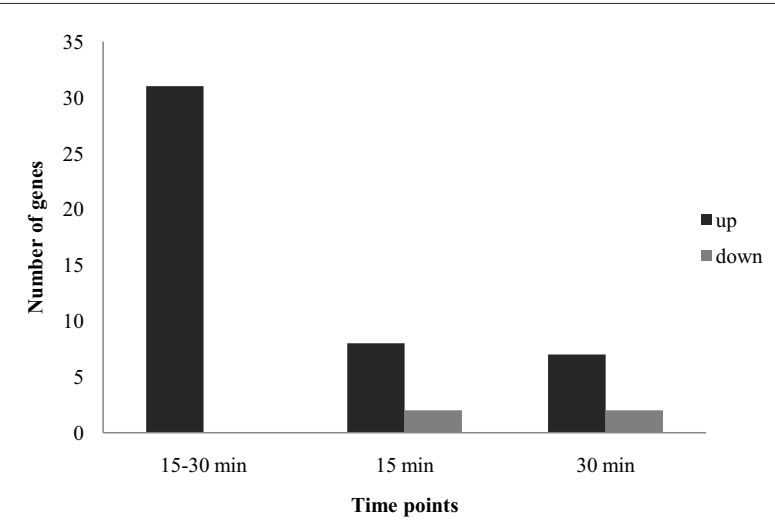

Figure 3 Genes differentially regulated in a time dependent manner in 4-d-old etiolated seedlings subjected to $50 \mathrm{ng}$ of raphanusanin (Ra) treatment over time. Number of genes up-and downregulated by Ra after $15 \mathrm{~min}$ and/or $30 \mathrm{~min}$ time points. To clarify, the genes expression levels ( $\leq 1.5$ or $\geq 0.6$ ) were excluded from the total number of differentially regulated genes.

\section{Discussion}

In this study, we constructed a Ra-specific subtraction library and further selected 33 genes based on the expression analysis to analyse their functional correlation with the early blue-light response. The existence of highly specific genes and low percentages of housekeeping genes indicate that the subtraction was effectively performed for the $\mathrm{Ra}^{+}-\mathrm{Ra}$ - library. Since SSH is expected to normalise the DNA population, the less prevalent genes and highly redundant genes contained in the $\mathrm{Ra}^{+}-\mathrm{Ra}^{-}$library indicate that the normalisation was successful. The abundance of functionally annotated genes and, in particular, the high proportion of genes related to signalling suggests that $\mathrm{Ra}$ activates distinct genetic networks. This high subtractive efficiency allowed us to monitor the expression of many genes in different biochemical or physiological pathways in which $\mathrm{Ra}$ is implicated.

\section{Does raphanusanin modulate cellular defence?}

The molecular evidence reported herein indicates that raphanusanin $(\mathrm{Ra})$ is involved in several metabolic processes in which many defence-associated genes are upregulated and very few genes are down-regulated (Table 3 and Figure 3). Accordingly, questions arise with regard to why Ra activates many defence-associated genes and how this is associated with cellular defence. Ra induced the regulation of leucine-rich repeat (LRR) proteins, LRR transmembrane proteins, the receptor-like kinase (ERECTA), serine-threonine kinases, and glycoproteins (Table 2). Several studies have emphasised the conserved functions of LRR domains, LRR transmembrane proteins [47], membrane-spanning glycoproteins such as hydroxyl proline-rich glycoproteins [48], RLKs such as ERECTA $[13,49]$, and cytoplasmic serine-threonine kinases, such as $\mathrm{Ca}^{+}$inducers. CBL-interacting protein kinase (CIPK1) [16] acted as a resistant (R) protein in the defence system. Van der Biezen and Jones hypothesised that $R$ proteins may function as regulatory adaptors in plant apopto- 
Table 4: Summary of expression ratio of 33 ESTs from highly regulated Ra-induced genes over BL at different fluences at indicated time points versus dark-grown seedlings

\begin{tabular}{|c|c|c|c|c|c|c|c|c|c|c|}
\hline Familya & Function & & $5 \mathrm{~min}$ & & & $15 \mathrm{~min}$ & & & $30 \mathrm{~min}$ & \\
\hline & & Continuous 1 & Continuous2 & pulse & Continuous 1 & Continuous2 & pulse & Continuous 1 & Continuous2 & pulse \\
\hline Ubi-3 & 1 & $2.8 \pm 0.6$ & $1.34 \pm 0.2$ & $2.5 \pm 0.5$ & $6 \pm 0.7^{*}$ & $2.7 \pm 0.2^{*}$ & $2.8 \pm 0.4^{*}$ & $4.3 \pm 0.6^{*}$ & $1.8 \pm 0.5$ & $2.3 \pm 0.3$ \\
\hline CSN3 & 1 & $1.5 \pm 0.1$ & $1.23 \pm 0.1$ & $3.8 \pm 0.5^{*}$ & $2.9 \pm 0.3 *$ & $1.97 \pm 0.2^{*}$ & $1.13 \pm 0.1$ & $2.02 \pm 0.2^{*}$ & $1.3 \pm 0.1$ & $0.98 \pm 0.1$ \\
\hline Zinc Finger & 1 & $1.3 \pm 0.2$ & $0.9 \pm 0.2$ & $2.6 \pm 0.3^{*}$ & $2.68 \pm 0.6$ & $1.5 \pm 0.6$ & $1.23 \pm 0.2$ & $1.95 \pm 0.4$ & $2.2 \pm 0.3$ & $0.93 \pm 0.3$ \\
\hline PMF1 & 1 & $1.5 \pm 0.2$ & $3.2 \pm 0.5$ & $2.14 \pm 0.4$ & $2 \pm 0.2$ & $2.8 \pm 0.3^{*}$ & $1.2 \pm 0.2$ & $2.5 \pm 0.2^{*}$ & $3.8 \pm 1$ & $1.12 \pm 0.1$ \\
\hline CND41 & 1 & $0.8 \pm 0.2$ & $0.78 \pm 0.1$ & $1.04 \pm 0.1$ & $0.62 \pm 0.1$ & $\underline{0.25 \pm 0.2}$ & $1.96 \pm 0.2^{*}$ & $1.53 \pm 0.3$ & $1.25 \pm 0.2$ & $1.81 \pm 0.3$ \\
\hline CUL1 & 1 & $1.19 \pm 0.1$ & $1.65 \pm 0.1$ & $4.1 \pm 0.7^{*}$ & $1.56 \pm 0.2$ & $1.85 \pm 0.1 *$ & $1.49 \pm 0.1$ & $2.7 \pm 0.2^{*}$ & $2.8 \pm 0.6$ & $0.89 \pm 0.2$ \\
\hline NTRA & 2 & $2.7 \pm 0.4$ & $1.8 \pm 0.5$ & $2.3 \pm 0.3$ & $3.2 \pm 0.6$ & $2.98 \pm 0.6$ & $2.15 \pm 0.4$ & $1.3 \pm 0.1$ & $1.14 \pm 0.2$ & $0.92 \pm 0.1$ \\
\hline ERECTA & 2 & $5.3 \pm 0.6^{*}$ & $16.5 \pm 2.3^{*}$ & $1.8 \pm 0.2$ & $9.16 \pm 1.7^{*}$ & $5.5 \pm 1.5$ & $2.2 \pm 0.3$ & $3.23 \pm 0.3^{*}$ & $3.85 \pm 0.8$ & $1.9 \pm 0.2$ \\
\hline CAT & 2 & $1.37 \pm 0.2$ & $0.89 \pm 0.1$ & $0.7 \pm 0.1$ & $0.42 \pm 0.1 *$ & $0.22 \pm 0.1 *$ & $0.58 \pm 0.1$ & $0.35 \pm 0.1 *$ & $1 \pm 0.2$ & $2.2 \pm 0.2^{*}$ \\
\hline MBP1 & 2 & $1.01 \pm 0.1$ & $0.88 \pm 0.1$ & $2.1 \pm 0.3$ & $2.76 \pm 0.4^{*}$ & $1.86 \pm 0.3$ & $1.12 \pm 0.1$ & $4.32 \pm 1$ & $2.08 \pm 0.5$ & $1.3 \pm 0.4$ \\
\hline CIPKI & 2 & $1.8 \pm 0.3$ & $0.89 \pm 0.2$ & $1.05 \pm 0.1$ & $2.39 \pm 0.2^{*}$ & $1.34 \pm 0.2$ & $1.4 \pm 0.2$ & $2.98 \pm 0.4^{*}$ & $2 \pm 0.4$ & $2.2 \pm 0.6$ \\
\hline САМТАЗ & 2 & $0.77 \pm 0.1$ & $1.21 \pm 0.1$ & $0.98 \pm 0.1$ & $1.98 \pm 0.2^{*}$ & $1.8 \pm 0.1 *$ & $2.63 \pm 0.2^{*}$ & $1.03 \pm 0.1$ & $1.3 \pm 0.1$ & $1.2 \pm 0.3$ \\
\hline DRP & 2 & $2.03 \pm 0.4$ & $4.9 \pm 1.2$ & $3.8 \pm 0.6$ & $2.2 \pm 0.2^{*}$ & $3.8 \pm 0.5^{*}$ & $2 \pm 0.3$ & $3.9 \pm 0.9$ & $5.98 \pm 0.2^{*}$ & $1.79 \pm 0.3$ \\
\hline RMB2 & 2 & $1.22 \pm 0.1$ & $1.35 \pm 0.3$ & $0.91 \pm 0.1$ & $1.89 \pm 0.3$ & $1.81 \pm 0.2$ & $1.2 \pm 0.1$ & $1.43 \pm 0.2$ & $1.25 \pm 0.1$ & $1.01 \pm 0.2$ \\
\hline Glycoprotein & 2 & $0.6 \pm 0.1$ & $0.56 \pm 0.2$ & $0.78 \pm 0.1$ & $1.73 \pm 0.2$ & $2.57 \pm 0.4$ & $0.75 \pm 0.1$ & $3.22 \pm 0.5^{*}$ & $2 \pm 0.8$ & $2.4 \pm 0.3^{*}$ \\
\hline ACCO & 2 & $1.12 \pm 0.2$ & $1.09 \pm 0.1$ & $3.14 \pm 0.3^{*}$ & $1.98 \pm 0.2$ & $1.83 \pm 0.3$ & $1.56 \pm 0.3$ & $3.15 \pm 0.7$ & $1.93 \pm 0.5$ & $0.91 \pm 0.1$ \\
\hline LRT & 2 & $1.06 \pm 0.1$ & $1.12 \pm 0.1$ & $0.9 \pm 0.1$ & $0.95 \pm 0.2$ & $0.85 \pm 0.2$ & $0.8 \pm 0.1$ & $4.3 \pm 1.9$ & $2.97 \pm 0.4^{*}$ & $9.5 \pm 3$ \\
\hline Kinesin & 3 & $1.9 \pm 0.5$ & $1.45 \pm 0.4$ & $2.55 \pm 0.8$ & $3.2 \pm 0.2^{*}$ & $2.65 \pm 0.7$ & $3.1 \pm 1.1$ & $4.33 \pm 0.9$ & $2.15 \pm 0.2^{*}$ & $1.41 \pm 0.3$ \\
\hline CCR4-NOT & 4 & $2.89 \pm 0.3^{*}$ & $3.67 \pm 0.2^{*}$ & $2.3 \pm 0.2^{*}$ & $4.5 \pm 1.2$ & $1.88 \pm 0.3$ & $1.3 \pm 0.1$ & $6.1 \pm 1.2^{*}$ & $1.98 \pm 0.5$ & $1.68 \pm 0.2$ \\
\hline PPFP & 4 & $1.48 \pm 0.1$ & $6.8 \pm 1.5$ & $2 \pm 0.2$ & $1.8 \pm 0.2$ & $\underline{3 \pm 0.4^{*}}$ & $\underline{0.33 \pm 0.1 *}$ & $1.39 \pm 0.2$ & $2.67 \pm 0.6$ & $1.6 \pm 0.5$ \\
\hline PPEase & 4 & $2.4 \pm 0.3$ & $1.2 \pm 0.2$ & $7.9 \pm 1.3^{*}$ & $2.3 \pm 0.2^{*}$ & $2.4 \pm 0.4$ & $4.5 \pm 0.7^{*}$ & $3.3 \pm 0.3^{*}$ & $2.8 \pm 0.2^{*}$ & $1.25 \pm 0.2$ \\
\hline PTI1 & 4 & $2.8 \pm 0.5$ & $4 \pm 0.6 *$ & $2.05 \pm 0.6$ & $2 \pm 0.3$ & $1.5 \pm 0.5$ & $0.98 \pm 0.2$ & $1.7 \pm 0.1$ & $1.1 \pm 0.1$ & $1.98 \pm 0.3$ \\
\hline KT & 4 & $0.73 \pm 0.1$ & $1.35 \pm 0.2$ & $1.8 \pm 0.2$ & $1.65 \pm 0.1$ & $1.5 \pm 0.6$ & $\underline{0.38 \pm 0.1 *}$ & $1.55 \pm 0.3$ & $1.35 \pm 0.2$ & $0.82 \pm 0.1$ \\
\hline SDR & 3 & $0.85 \pm 0.2$ & $0.7 \pm 0.1$ & $1.09 \pm 0.1$ & $2.64 \pm 0.1 *$ & $1.8 \pm 0.2$ & $0.9 \pm 0.1$ & $1.09 \pm 0.1$ & $1.23 \pm 0.1$ & $0.85 \pm 0.1$ \\
\hline PKC & 4 & $0.5 \pm 0.3$ & $0.25 \pm 0.2^{*}$ & $1.4 \pm 0.1$ & $0.77 \pm 0.1$ & $0.18 \pm 0.1 *$ & $0.78 \pm 0.2$ & $0.65 \pm 0.1$ & $0.83 \pm 0.1$ & $1.3 \pm 0.1$ \\
\hline Pescadillo & 2 & $0.5 \pm 0.1 *$ & $0.6 \pm 0.2$ & $0.8 \pm 0.2$ & $0.82 \pm 0.1$ & $\underline{0.23 \pm 0.1^{*}}$ & $\underline{3.37 \pm 0.4^{*}}$ & $1.25 \pm 0.5$ & $0.8 \pm 0.1$ & $2.35 \pm 0.3$ \\
\hline GTPase & 2 & $0.94 \pm 0.1$ & $0.83 \pm 0.1$ & $2.6 \pm 0.3 *$ & $1.13 \pm 0.1$ & $\underline{0.42 \pm 0.2}$ & $\underline{3.55} \pm 0.7$ & $0.92 \pm 0.1$ & $0.47 \pm 0.3$ & $3.1 \pm 0.3^{*}$ \\
\hline
\end{tabular}


Table 4: Summary of expression ratio of 33 ESTs from highly regulated Ra-induced genes over BL at different fluences at indicated time points versus dark-grown seedlings (Continued)

\begin{tabular}{|c|c|c|c|c|c|c|c|c|c|c|}
\hline GH3 & 3 & $1.1 \pm 0.1$ & $1.17 \pm 0.1$ & $1.4 \pm 0.3$ & $1.34 \pm 0.2$ & $1.8 \pm 0.3$ & $2.1 \pm 0.3$ & $1.09 \pm 0.1$ & $1.12 \pm 0.1$ & $2.3 \pm 0.5$ \\
\hline PLC & 4 & $0.98 \pm 0.1$ & $0.87 \pm 0.2$ & $1.32 \pm 0.1$ & $0.7 \pm 0.1$ & $1.12 \pm 0.1$ & $0.93 \pm 0.1$ & $1.1 \pm 0.3$ & $0.7 \pm 0.1$ & $2.89 \pm 0.4^{*}$ \\
\hline$P G \beta 1$ & 4 & $0.98 \pm 0.2$ & $1.16 \pm 0.1$ & $1.55 \pm 0.2$ & $1.3 \pm 0.1$ & $1.85 \pm 0.4$ & $3.3 \pm 0.5^{*}$ & $1.4 \pm 0.1$ & $1.55 \pm 0.2$ & $2.5 \pm 0.5$ \\
\hline Peroxidase & 2 & $2.76 \pm 0.3^{*}$ & $0.95 \pm 0.1$ & $2.5 \pm 0.6$ & $1.8 \pm 0.4$ & $2.5 \pm 0.2^{*}$ & $1.2 \pm 0.1$ & $1.23 \pm 0.1$ & $1.05 \pm 0.1$ & $1.3 \pm 0.3$ \\
\hline USP & 2 & $1.03 \pm 0.2$ & $0.9 \pm 0.2$ & $0.69 \pm 0.1$ & $1 \pm 0.1$ & $1.2 \pm 0.1$ & $0.5 \pm 0.1 *$ & $1.08 \pm 0.1$ & $1.4 \pm 0.3$ & $2.9 \pm 0.7$ \\
\hline $3 \mathrm{KCS} 4-21$ & 3 & $1.1 \pm 0.1$ & $0.95 \pm 0.1$ & $1.7 \pm 0.2$ & $1.18 \pm 0.2$ & $1.14 \pm 0.1$ & $1.23 \pm 0.2$ & $0.81 \pm 0.1$ & $0.9 \pm 0.1$ & $2.9 \pm 0.4^{*}$ \\
\hline
\end{tabular}

${ }^{a}$ one representative clone for each gene is shown. Three independent biological replicates were performed. Value \pm s.e. indicates expression ratio of Treatment/Control after normalization \pm

standard error of the mean $(n=3)$. Genes that differ significantly (student $t$ test $p$-value less than 0.05$)$ in their expression between the treatment and control are marked with an asterisk (*). Bold represents expression ratios ( $\geq 1.5$ or $\leq 0.6)$. Underlined values show the opposite regulation on different fluences. The functional categories are 1: protein metabolism/binding, 2 : defence, 3 : metabolism, 4: Unclassified. Continuous 1: $0.45 \mu \mathrm{mol} \mathrm{m}^{-2} \mathrm{~s}^{-1}$; Continuous 2: $0.1 \mu \mathrm{mol} \mathrm{m} \mathrm{m}^{-2} \mathrm{~s}^{-1}$; Pulse: $30 \mu \mathrm{mol} \mathrm{m} \mathrm{m}^{-2} \mathrm{~s}^{-1}$ for $15 \mathrm{sec}$. The values shown represent fold change (treatment vs. control). 


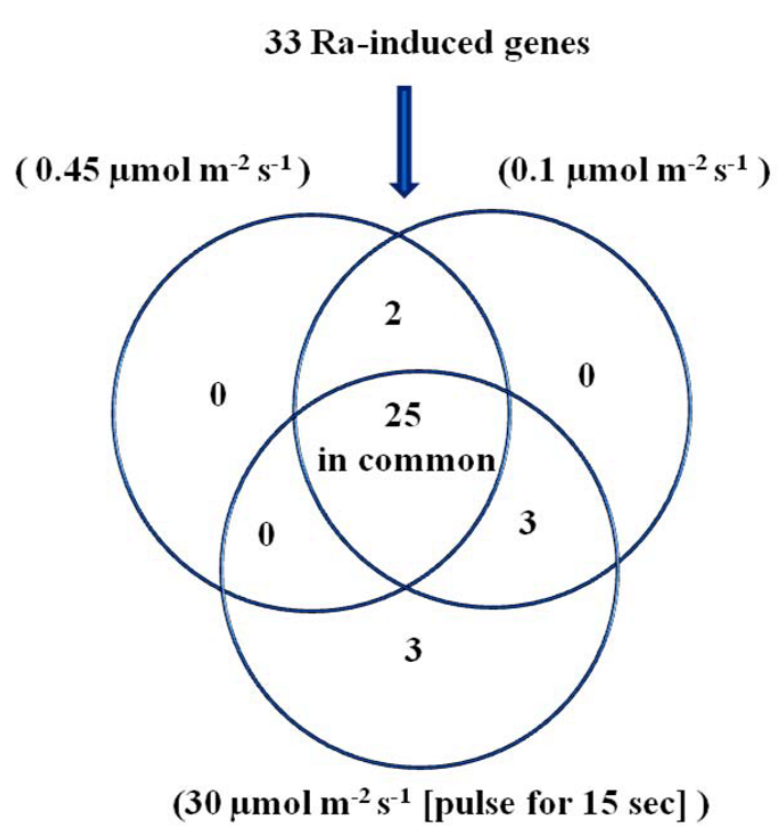

Figure 4 Response of raphanusanin (Ra)-induced genes to three different blue light (BL) intensities $\left(0.45 \mu \mathrm{mol} \mathrm{m}^{-2} \mathrm{~s}^{-1}\right), \mathrm{BL}(0.1$ $\left.\mu \mathrm{mol} \mathrm{m}{ }^{-2} \mathrm{~s}^{-1}\right), \mathrm{BL}\left(30 \mu \mathrm{mol} \mathrm{m}^{-2} \mathrm{~s}^{-1}\right.$, pulse for $\left.15 \mathrm{sec}\right)$. Venn diagram indicates the differential expression of genes upon the three different treatments of $B L$ at different time points.

somes that are activated by pathogen-derived avirulence (Avr) signals [50].

Moreover, Ra-induced genes (Table 2), such as the antioxidant genes NTRA, CAT, and peroxidase, the channel activators CAMTA3, KT, POT, and $\mathrm{H}+$ ATPase, the

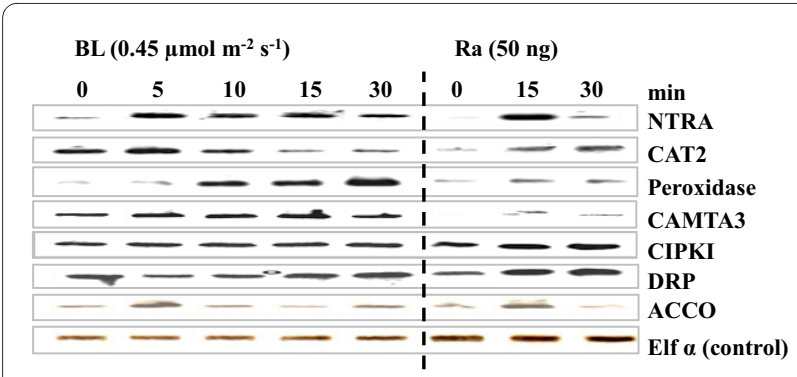

Figure $5 \mathrm{BL}$ and $\mathrm{Ra}$ induce the genes related to growth inhibition and cellular defence. Time courses of transcript levels of seven genes involved in growth inhibition pathways relative to controls following treatment with BL and Ra at the indicated concentrations were validated by reverse transcriptase-polymerase chain reaction (RT-PCR). Transcript levels of seven genes, NADPH-dependent thioredoxin reductase A (NTRA), catalase2 (CAT2), peroxidase, calmodulin- binding transcription factor 3 (CAMTA3), SNF-1 related protein kinase (CIPK1), disease resistance protein (DRP), and ACC oxidase. The bottom panels show the elongation factor a (ef1a) as loading control. Primers for all genes are specific to transcripts from the respective cDNA. The data represents the typical gel image of one of three replicates. BL: blue light; Ra: raphanusanin lignin-associated genes DRP and peroxidase (overlapping functions as antioxidants), the membrane-associated Gprotein Rab, and CPOX are involved in the signal transduction network of the HR (hypersensitive response)related programmed cell death (PCD) in plants [47]. The earliest cellular response upon $\mathrm{R}$ activation includes a rapid burst of reactive oxygen species (ROSs), leading to a dramatic increase in oxidation reactions, increased transmembrane ion flux, especially of $\mathrm{Ca}^{+}, \mathrm{K}^{+}$and $\mathrm{H}^{+}$, the cross-linking of phenolic moieties with cell-wall components and the reinforcement of the plant cell wall (callose and lignins), the transient activation of protein kinases (wound-induced and salicylic acid (SA)-induced kinases), the production of defensins and phytoalexins, the synthesis of resistance $(\mathrm{R})$ proteins, and transcriptional reprogramming [51].

Many reports have highlighted the involvement of ion channels, especially that of $\mathrm{Ca}^{+}$, on the plasma membrane during early defence signalling in Arabidopsis, tomato, tobacco, and parsley [52-54]. CAMTA 3 mutants attenuated the propagation of a virulent strain of the bacterial pathogen Pseudomonas syringae and the fungal pathogen Botrytis cinerea during Arabidopsis development [37]. The rapid and sustained increase in $\mathrm{Ca}^{+}$is necessary for the oxidative burst and hypersensitive cell death facilitated by the plant disease resistance gene, RPM1, in Arabidopsis [55]. Subsequently, the production of ROSs leads to cell-wall fortification, the induction of defence gene expression, and PCD $[55,56]$. The NADPH thioredoxin (NTR) is involved in the signalling associated with apoptosis and hypersensitivity to stress in Arabidopsis [57,58]. The loss of function in the Arabidopsis double mutant ntra ntrb plant results in hypersensitivity to buthionine sulfoximine (BSO), a specific inhibitor of glutathione biosynthesis, demonstrating the involvement of ntr genes in the glutathione pathway [59]. Moreover, DRP has been suggested to play a role in defence responses and in promoting lignin deposition in juglone-stressed soybeans [15]. Peroxidase is associated with the catalytic reactions of $\mathrm{H}_{2} \mathrm{O}_{2}$, and many studies demonstrate the peroxidasereduced cell-wall extensibility and elevated lignin content in stressed plants [60-65]. Furthermore, Arabidopsis lesion initiation 2 (LIN2) encodes CPOX, and the lin2 mutant develops lesions on its leaves and siliques in a developmentally regulated and light-dependent manner [27].

The abundance of genes involved in protein metabolism is remarkable, especially those genes comprising the ubiquitin-proteosome system, HSP90, PMF1, CSN3, UBQ3, CUL1, KEG (a Novel RING E3), and $\mathrm{C}_{3} \mathrm{HC}_{4}$-type Ring Finger. The ubiquitin-proteosome pathway is likely to be an important modulator of the R-gene-triggered resistance [47]. One study showed that one regulator of 
R-genes, SGT1 (suppressor of G2 allele of SKP1), is essential for the function of the Skp1-cullin-F-box protein (SCF) E3 ubiquitin ligase complex that targets proteins for degradation by the $26 \mathrm{~S}$ proteosome. RAR1 (required for Mla-dependent resistance1), SGT1, and HSP90 are thought to form a complex that mediates the folding of $\mathrm{R}$ proteins into functional complexes [66]. In addition, the COP9 signalosome, a multiprotein complex involved in the recognition of correct substrates for protein degradation, is required for the resistance to tobacco mosaic virus mediated by the tobacco TIR-NB-LRR $\mathrm{N}$ protein [67]. Moreover, RING-finger E3 ligases in Arabidopsis are involved in the RPM1- and RPS2-mediated elicitation of HR [68]. The knock-down of RING1 transcripts with an artificial microRNA (amiR-R1159) leads to hyposensitivity to the pathogenic toxin fumonisin B1 (FB1), whereas over-expression of RING1 confers hypersensitivity [69]. Furthermore, Arabidopsis CUL1 (a subunit of E3 ligase) was assembled into the SCF complex containing COI1, an F-box protein required for the response to jasmonates (JA), which regulate plant fertility and defence responses [70], and KEG, an E3 ligase that acts as a negative regulator of abscisic acid (ABA) signalling in Arabidopsis. The KEG mutant undergoes growth arrest immediately after germination, suggesting an increase in ABA signalling that regulates the plant survival in unfavourable conditions [30].

Moreover, Ra positively regulated MBP1 (myrosinbinding protein or jasmonate-inducible protein), 1-aminocyclopropane-1-carboxylic acid oxidase (ACCO) (ethylene-forming enzyme), and CAMTA3 (also called ethylene-forming calmodulin-binding protein 1), also correlating with R-gene functions in the hormonal control of PCD activation [47]. The hormone ethylene (ET) is involved in stimulating developmental and inducible forms of PCD during aerenchyma formation [71]. ET positively contributes to HR cell death and lesion size in TMV-infected tobacco leaves, as well as in tomato plants challenged with an avirulent Xanthomonas strain [72,73]. Moreover, infection with TMV activates the SIPK cascade (a tobacco mitogen-activated protein kinase MAPK) and induces ethylene biosynthesis. It also induces ACC oxidase [38] because pest-induced wounding increased the ACC oxidase protein in the conifer stem, whereas the methyl jasmonate $(\mathrm{MJ})$ treatment produced a higher and more rapid ACC oxidase response, indicating the coordinated action of ET and JA in defence [12]. Furthermore, JA has been shown to promote cell death events induced by singlet oxygen in the protoplasts of the conditional $\mathrm{flu}$ mutant in Arabidopsis [74] and to affect hairpin-induced hypersensitive cell death in tobacco suspension-cultured BY-2 cells [75]. Genes encoding myrosinase-binding proteins (MBPs) were shown to be $\mathrm{H}_{2} \mathrm{O}_{2}$-responsive [76], and $\mathrm{H}_{2} \mathrm{O}_{2}$ induces PCD in Arabidopsis and other species [77-80].

$\mathrm{Ra}$ has also been shown to induce the regulation of the phosphatidic acid precursors, phospholipase C (PLC) and phospholipase D (PLD), both of which modulate the PCD as lipid-based signals. For example, the expression of the phosphoinositide-specific phospholipase C gene, OsPIPLC1, was activated in rice cells after benzothiadiazole (BTH) treatment and in BTH-treated cells after Xanthomonas oryza pv. oryza (Xoo) infection, resulting in the production of an oxidative burst and hypersensitive cell death [17]. The coactivation of PLC, PLD, and ET induces PCD in tomato, and inhibitors of the PLC and PLD signalling pathway intermediates greatly reduce the chemical-induced cell death of suspension-cultured tomato (Lycopersicon esculentum Mill.) cells (line MsK8). Ethylene, while not inducing cell death when applied alone, stimulates chemical-induced cell death, indicating that the activation of the PLC, PLD, and ET signalling pathways is required for cell death [18].

The primary role of $\mathrm{Ra}$ in hypocotyl growth inhibition, as demonstrated by Moehninsi et al. [3], is likely due to cell-wall strengthening via the induction of lignin to protect cells from environmental stimuli. Alternatively, the interactions between defence and growth suppression could also be a main reason for induction of genes involved in both defence and growth suppression signalling. In support of this notion, one study shows that the indirect activation of the MAPK cascade in $\mathrm{H}_{2} \mathrm{O}_{2}$-treated Arabidopsis protoplasts induced the expression of genes involved in defence against oxidative stress and suppressed those associated with growth [81]. In our $\mathrm{Ra}^{+}-\mathrm{Ra}^{-}$ library, four genes thought to be implicated in the functional roles of growth inhibition, DRP, peroxidase, rapid alkalinisation factor 23 (RALF23), and CSN3, were upregulated in response to Ra. RALF23 is associated with defence via its activation of MAPKs and the induction of medium alkalinisation, leading to growth arrest $[19,82]$. Moreover, a rapid transient up-regulation of CSN3 is observed in response to various growth inhibition stimuli [3]. In addition, the up-regulation of cellular biogenesis genes such as actin, profilin, cellulose synthase 5-transferase, kinesin, and $\alpha$-tubulins may also be involved in elaborate cell-wall thickening.

\section{Raphanusanin-induced gene networks associated with early blue-light $(B L)$ signalling}

An attempt to identify the functional correlations between $\mathrm{Ra}$ and light regulation led us to monitor the expression of many genes in response to different fluences of early BL. We found that the selected 33 genes were commonly regulated under $\mathrm{BL}$ in an intensity or duration-dependent manner (Figure 4 and Table 4). In addition, most gene expression patterns largely over- 
lapped between the $\mathrm{BL}$ and exogenous Ra treatments. The above results contribute to an emerging body of evidence indicating that Ra may be functionally correlated with early $\mathrm{BL}$, and thereby affects the regulation of genes involved in establishing plant acclimation to light.

Early blue light effects include the hyperpolarisation of the cell membrane, increased input resistance, and induction of carotenoid biosynthesis, all of which can be observed within the first $30 \mathrm{~min}$ after the exposure to light. In addition, light-induced mRNA synthesis of some fast light-regulated genes can be detected within five min after a light pulse [83-89]. Our data are in agreement with the above findings that many genes are induced within the first $30 \mathrm{~min}$, including membrane transporters and many defence-associated and chloroplast-associated genes. The overlapping expression of many genes, especially those with conserved functions involved in early light responses between $\mathrm{BL}$ and $\mathrm{Ra}$, indicates that BL and Ra may use a similar signalling mechanism. Many studies show that a rapid phot1-dependent $\mathrm{Ca}^{2+}$ concentration increase occurs in response to blue-light exposure [9093], thereby triggering the inhibition of hypocotyl growth $[94,95]$. In addition, the proton extrusion of the phot1mediated stomatal opening is mediated by an $\mathrm{H}^{+}$-ATPase or proton pump, which is triggered by phosphorylation [96-98]. Furthermore, Pedmale and Liscum demonstrated the links between phot1, NPH3, and E3 basedubiquitin-dependent proteosomal degradation in lightmediated processes [99]. The transporters (especially POT, and $\mathrm{H}^{+}$-ATPase), membrane bound kinases, E3 ligases, and genes that trigger $\mathrm{Ca}^{2+}$ influx, such as $1,4,5$ IP3-catalyzing enzyme PLC, CAMTA3, and CIPKI, are differentially regulated in response to both $\mathrm{BL}$ and $\mathrm{Ra}$. In addition, under low-BL fluence rates, phot1 is the principle photoreceptor regulating both growth inhibition and phototropism [100-102]. With regard to our experimental system, the ability of unilateral irradiation with low light (LL) fluences of BL to inhibit growth is expected to be under PHOTs control. Taken together, the differential expression of genes induced by BL in this context is likely to be triggered by PHOTs, and the unique signalling cascades triggered by PHOTs may reflect crosstalk between the light and defence systems. This notion is supported by a report showing that the FMN moiety of PHOT1 confers redox sensitivity that leads to its activation [103,104]. Many previous studies demonstrated BL-induced gene expression profile changes using experimental conditions that include high light (HL) and long time-exposure [105107]. Our data showing gene expression profiles within the first $30 \mathrm{~min}$ under LL intensities are informative with regard to the signalling pathways responsive to variable fluence rates and early light responses while plants are acclimating to sudden environmental changes. This information may be useful for identifying the photosen- sory signalling networks that interact with cellular defence.

\section{Raphanusanin may mediate the links between the light signalling and defence responses}

Because $\mathrm{Ra}$ induces the up-regulation of many defencerelated genes, the obvious question is how light affects the Ra-induced signalling cascades involved in the induction of transcription factors and their target genes. Earlier studies have pointed out that light not only modulates the defence responses via its influence on biochemistry and plant development, but is also essential for the development of resistance [108]. For examples, light is necessary for development of the resistance responses to Pseudomonas solanacearum in tobacco (Nicotiana tubacum) [109], Xanthomonas oryzae in rice (Oryza sativa) [110], and Pseudomonas syringae and Peronospora parasitica in Arabidopsis [111,112]. There are also several examples of plant responses to isolated pathogenic elicitors that are light-dependent. Leaf necrosis on tomato in response to an avirulence elicitor from Cladosporium fulvum is substantially reduced in the dark [113], cell death induced by the fungal toxins AAL from Alternaria alternata [114] requires light, and one of the pathogenic toxins (FB1) capable of inducing cell death in Arabidopsis protoplasts is light-dependent and requires phytohormones, as well as the SA, JA, and ET-mediated signalling pathways [115]. The importance of the cellular energy status and redox balance $\left(\mathrm{H}_{2} \mathrm{O}_{2} / \mathrm{ROS}\right)$ produced in chloroplasts and plant stress responses in the regulation of PCD is supported by the finding that various forms of cell death triggered by pathogens, or spontaneously in lesion-mimic mutants, are light-dependent [88,110,116119]. Additionally, at least some of the pathways involved in the biosynthesis of the major-related hormones, JA, $\mathrm{SA}$, and ABA, are located in the chloroplast, thus revealing a role for photosynthesis in both abiotic and biotic stress responses [87,108]. Considering that, many Rainduced genes involved in the predicted PCD pathways may simply reflect the light-dependent manner of PCD, and the roles of $\mathrm{Ra}$ in cellular defence may be dependent upon light.

\section{Conclusions}

This is the first report on comprehensive survey of transcriptional regulation in response to the light-induced growth inhibitor, Ra. Although physiological evidence for it roles in the inhibition of hypocotyls growth, microtubule orientation, and inhibition of apical dominance have been demonstrated, the molecular mechanisms underlying regulation by $\mathrm{Ra}$ are still limited. Our data offer the comprehensive understanding of transcriptional regulation in etiolated radish seedlings in response to $\mathrm{Ra}$ and its functional correlation with BL. We also provide a number 
of genes that are regulated in response to Ra that could be tested in many functional analyses to increase our understanding of the roles of Ra. Most of the genes important for cellular defence are highly regulated by both $\mathrm{Ra}$ and $\mathrm{BL}$. These results suggest the link between $\mathrm{Ra}$ and cellular defence and light signalling. Further research on the biological relevance of the effects of $\mathrm{Ra}$ on plant-lightmicrobe interactions and the analysis of null mutants in specific pathways should provide new insights into the role of $\mathrm{Ra}$ in cellular defence.

\section{Methods}

\section{Plant material and plant growth}

Sakurajima radish (Raphanus sativus var. hortensis $\mathrm{f}$. gigantissimus Makino) seeds were germinated in vermiculite moistened with water in large trays $(37 \times 60 \times 14$ $\mathrm{cm}$ ) in absolute darkness at $25^{\circ} \mathrm{C}$. About $3 \mathrm{~d}$ later, uniform seedlings were transplanted to small trays $(8.5 \times 17.7 \times$ $3.5 \mathrm{~cm})$ containing moist vermiculite under extremely dim green 'safelight' $\left(<0.01 \mu \mathrm{mol} \mathrm{m}^{-2} \mathrm{~s}^{-1}\right)$ and incubated in the dark at $25^{\circ} \mathrm{C}$ for $1 \mathrm{~d}$.

\section{Light treatments and unilateral application of raphanusanin}

Light treatments were performed using an LED array (NSPB 520S; NICHIA for blue light (BL). Etiolated seedlings (with a hypocotyl length of about $4 \mathrm{~cm}$ ) were unilaterally illuminated with $\mathrm{BL}$ (LED array; $\mathrm{m}_{\mathrm{ix}}$ : $470 \mathrm{~nm}$; half band width: $20 \mathrm{~nm}$ ) for $30 \mathrm{~min}$ at $25^{\circ} \mathrm{C}$. The incident energy was $0.45 \mu \mathrm{mol} \mathrm{m} \mathrm{m}^{-2} \mathrm{~s}^{-1}, 0.1 \mu \mathrm{mol} \mathrm{m} \mathrm{m}^{-2} \mathrm{~s}^{-1}$, or a pulse (30 $\mu \mathrm{mol} \mathrm{m} \mathrm{m}^{-2} \mathrm{~s}^{-1}$ for $\left.10 \mathrm{sec}\right)$ at plant level. Fluence rates were assessed with a LI-COR LI-189 photometer. Raphanusanin was isolated from fresh radish roots based on the procedures described by Kosemura et al., 1997. An estimated endogenous amount of $50 \mathrm{ng}$ of Ra was mixed with $0.5 \mathrm{mg}$ of lanolin and unilaterally applied to the hypocotyls in a lengthwise manner from 0 to $2 \mathrm{~cm}$ below the hook of uniform four-day old etiolated seedlings. Control seedlings were also treated with $0.5 \mathrm{mg}$ lanolin. Treated seedlings were incubated in absolute darkness at $25^{\circ} \mathrm{C}$. All manipulations were performed under safelight $\left(>0.01 \mu \mathrm{mol} \mathrm{m}^{-2} \mathrm{~s}^{-1}\right)$

\section{Sample collection}

Etiolated four-day-old seedlings were unilaterally illuminated with $\mathrm{BL}\left(0.45 \mu \mathrm{mol} \mathrm{m}{ }^{-2} \mathrm{~s}^{-1}, 0.1 \mu \mathrm{mol} \mathrm{m}{ }^{-2} \mathrm{~s}^{-1}\right.$ or pulse $30 \mu \mathrm{mol} \mathrm{m} \mathrm{m}^{-2} \mathrm{~s}^{-1}$ for $\left.10 \mathrm{sec}\right)$ or treated with a unilateral application of raphanusanin (50 ng) using the same procedure mentioned above. The seedlings were harvested and immediately submerged in liquid nitrogen with minimal exposure to 'safelight' after the indicated time periods. Treated samples were immediately replaced in the dark box for 5,15 , or 30 min until harvested. Ten replicates (both control and treated samples) were harvested directly into liquid nitrogen after the following treatments.

\section{Subtraction library construction}

Suppression subtractive hybridization ( $\mathrm{SSH}$ ) was performed using a PCR-select cDNA subtraction kit (Clontech Laboratories, U.S.A.) according to the manufacturer's instructions (see detailed in additional file 1 and additional file 6).

\section{Determination of nucleotide sequences and sequence annotation}

Nucleotide sequences were determined with a DNA autosequencer (ABI 310 Applied Biosystems, USA) using Big-Dye terminators. All sequencing reactions involved either the standard M13 forward or reverse primers, and thus both the $5^{\prime}$ and $3^{\prime}$ sequences of each cDNA were obtained. The sequence text files were edited to remove vector sequence and ambiguous bases. Two reads from both ends of a clone were merged using the Codon Code Aligner based on pairwise alignments. The resulting sequences were then assembled by the Phrap program (Codon Code Aligner Sequence Assembler v3.0.1). The annotation is based on the best BLASTX match of the corresponding radish sequences against NCBI nonredundant protein sequences $(\mathrm{nr})$ (expect value $<0.01$ ) or TAIR Arabidopsis protein database. Physiological and biochemical classification of the clones were clustered according to GO annotations http://www.ebi.ac.uk/ GOA/.

\section{Selection of radish sequences and PCR primer design}

To identify the true reference gene for evaluating the gene expression level of raphanusanin-induced clones, seven housekeeping genes commonly used as controls for plant gene expression studies, elongation factor $1-\alpha$ (ef1 $\alpha)$, translation initiation factor (eIf2), 18s rRNA, actin, tubulin, ubiquitin and ribosomal protein (L4), were selected. Radish nucleotide sequences for tubulin, eIf2, ubiquitin, and ribosomal protein (L4) were obtained from the sequences of radish-subtracted library clones. The sequences of 18s rRNA and actin were obtained from radish ESTs deposited in the Gene bank database. The only ef $1 \alpha$ sequence found was from Arabidopsis thaliana, and the conserved region of this gene was selected for primer design. Seven primer pairs were designed based on these sequences for reference gene analysis using Primer3 software (see additional file 7). Fifty primer pairs for expression analysis of Ra-induced clones were designed based on the sequences of raphanusanininduced ESTs using Primer3 software (see additional file 8). BLASTX searches were performed against the sequence databases to confirm the gene specificity of the primer sequences. 


\section{Quantitative real-Time RT-PCR}

Total cellular RNA was extracted using a plant RNeasy Mini kit (QIAGEN, Germany) according to the manufacturer's instructions, followed by removal of contaminating genomic DNA with an RNase-Free DNase Set (QIAGEN, Germany). The first strand of cDNA was then synthesized using ThermoScript RNase H- RT (Invitrogen, USA) with an Oligo $(\mathrm{dT})_{12-18}$ primer (Invitrogen, USA). Three independent preparations of mRNA for each biological replicate were pooled to eliminate the inconsistent variation with sampling. Quantitative realtime PCR (qRT-PCR) was performed with a Thermal Cycler Dice ${ }^{\mathrm{TM}}$ Real Time System (TAKARA BIO INC., Japan) using SYBR ${ }^{\circ}$ Premix Ex Taq $^{\text {TM }}$ II (perfect real time) (TAKARA BIO INC., Japan). Reactions were performed in a total volume of $20 \mathrm{ul}$ containing $1 \times$ SYBR Premix Ex Taq II, $25 \mathrm{ng}$ of cDNA, $200 \mathrm{nM}$ of each specific sense and antisense primer, except for $18 \mathrm{~s}$ rRNA primers, for which $50 \mathrm{nM}$ of each was used. The two-step amplification program was: $95^{\circ} \mathrm{C}$ for $10 \mathrm{sec}, 45$ cycles of $95^{\circ} \mathrm{C}$ for $5 \mathrm{~s}$, followed by $61^{\circ} \mathrm{C}$ for $45 \mathrm{~s}$. Each sample had 2 replicates and non-template control to ensure reproducibility of the results. The real-time PCR efficiency was determined for each gene and each treatment via standard curve analysis. For this, each cDNA sample was pooled and then used as the PCR template (range of 50, 25, 12.5, 7.5, and $3.75 \mathrm{ng}$ ). All PCR reactions displayed efficiencies between $88 \%$ and $105 \%$. The specificity of the amplification was verified by both dissociation curve analysis and by visualization via gel electrophoresis. The most stable gene, eIf2 or ef $1 \alpha$, resulting from the control gene analysis was used as a reference gene. Relative expression levels were calculated using the comparative $\mathrm{C}_{\mathrm{T}}$ method. For each gene, expression values were normalized to the control samples (time zero), which were set to equal 1. Each value represents the average of three experimental replications. Within a single experiment, aliquots of the same cDNA synthesis reaction were used for real-time PCR amplification of each of the seven genes and all gene primers and CDNA combinations were amplified in duplicate in a single PCR run.

\section{RT-PCR detection}

The preparation of total RNA and first strand cDNA synthesis were performed as above. The PCR amplification was carried out in a $20 \mu \mathrm{l}$ reaction volume containing 100 ng of cDNA as template, $1 \times$ PCR buffer, $20 \mu \mathrm{M}$ dNTPs, $2.5 \mathrm{mM} \mathrm{MgCl}_{2}{ }^{+}, 0.4 \mu \mathrm{M}$ primers, and $0.5 \mathrm{U}$ of $\mathrm{HS}$ (Hot Start) Taq polymerase (Takara, Japan). The number of cycles used for the PCR reaction was adjusted for each gene to obtain barely visible bands by agarose gel electrophoresis. The PCR conditions were as follows: $95^{\circ} \mathrm{C}$ for 3 min, followed by the indicated number of cycles at $94^{\circ} \mathrm{C}$ for $30 \mathrm{~s}, 61^{\circ} \mathrm{C}$ for $30 \mathrm{~s}$, and $72^{\circ} \mathrm{C}$ for $45 \mathrm{~s}$. A final extension was carried out at $72^{\circ} \mathrm{C}$ for $5 \mathrm{~min}$. A $15 \mu \mathrm{l}$ aliquot of each PCR product was electrophoresed in a $3.5 \% \mathrm{w} / \mathrm{v}$ agarose gel. The primer pairs used for each gene were the same as those used for qRT-PCR.

\section{Statistical analyses}

Results $\left(C_{\mathrm{T}}\right.$ values $)$ from the Thermal Cycler Dice ${ }^{\mathrm{TM}}$ Real Time System were analyzed in Microsoft Excel. The levels present in different samples were calculated by F statistics $[\mathrm{F}=$ between tissue sample mean square/error mean square]. Other statistics defined in Table 2 were calculated using the method of Brunner et al., 2003 [120].

\section{Additional material}

\section{Additional file 1 Figure S1: Determination of subtraction efficiency. Additional file 2 Table S1: Physiological characterization of gene clus- ters \\ Additional file 3 Table S2: Biochemical characterization of gene clus- ters \\ Additional file 4 Figure S2: RNA transcription levels of housekeeping genes tested in the raphanusanin-treated sample, presented as the $C_{T}$ mean value at different time points. \\ Additional file 5 Table S3: Summary of statistics pertaining to the sta- bility of gene expression. \\ Additional file 6 Materials S1. Construction of subtraction library Additional file 7 Table S4: Primer sequences of seven housekeeping genes, the amplification length and the melting temperature of the amplified product. \\ Additional file 8 Table S5: Primer sequences of fifty ESTs, the amplifi- cation length and the melting temperature of the amplified product.}

\section{Authors' contributions}

MHS designed experiments, acquisition of data, compiled results and wrote the manuscript. KM carried out the organization of the data and manuscript editing. $\mathrm{HN}$ provided assistance in some experiments. $\mathrm{KY}, \mathrm{KH}$ and $\mathrm{HS}$ directed the project. All authors read and approved the final manuscript.

\section{Acknowledgements}

This work was supported by grants from Special Coordination Funds for Promoting Science and Technology, in part and Japanese Ministry of Education, Science, and Culture and Sports (Monbukagakusho).

\section{Author Details}

${ }^{1}$ Graduate School of Life and Environmental Sciences, University of Tsukuba, Ibaraki 305-8572, Japan and 2KNC Laboratories Co, Ltd, Hyogo 651-2271, Japan

Received: 18 April 2009 Accepted: 16 June 2010

Published: 16 June 2010

\section{References}

1. Hasegawa K, Shiihara S, Iwagawa T, Hase T: Isolation and identification of a new growth inhibitor, raphanusanin from radish seedlings and its role in light inhibition of hypocotyl growth. Plant Physiol 1982, 70:626-628

2. Noguchi H, Nishitani K, Bruinsma J, Hasegawa K: Phototropism in hypocotyls of radish: Il. role of cis- and trans-raphanusanins, and raphanusamide in phototropism of radish hypocotyls. Plant Physiol 1986, 81:980-983

3. Moehninsi, Yamada K, Hasegawa T, Shigemori H: Raphanusanin-induced genes and the characterization of RsCSN3, a raphanusanin-induced gene in etiolated radish hypocotyls. Phytochemistry 2008, 69:2781-2792. 
4. Hasegawa T, Yamada K, Kosemura S, Yanamura S, Hasegawa K Phototropic stimulation induces the conversion of glucosinolate to phototropism-regulating substances of radish hypocotyls. Phytochemistry 2000, 54:275-279.

5. Kosemura S, Yamamura S, Hasegawa K: Chemical studies on 4Methylthio-3-butenyl isothiocyanate from roots of japanese radish (Raphanus sativus L.) in connection with raphanusanins, phototropismregulating substances of radish hypotyls. Tetrahedron Letts 1993 , 34:481-484

6. Sakoda M, Hasegawa K, Ishizuka K: The occurrence in plants of the growth inhibitors, the raphanusanins. Phytochemistry 1991, 30:57-60.

7. Nakajima E, Yamada K, Kosemura S, Yamamura S, Hasegawa K: Effects of the auxin-inhibiting substances raphanusanin and benzoxazolinone on apical dominance of pea seedlings. J Plant Growth Regul 2004, 35:11-15.

8. Stephen F, Altschul, Thomas L, Madden, Alejandro A, Schäffer, Zhang Jinghui, Zhang Zheng, Miller Webb, David Lipman J: Gapped BLAST and PSI-BLAST: a new generation of protein database search programs. Nucleic Acids Res 1997, 25:3389-3402

9. Zou H, Wu Z, Qing Yang Q, Zhang X, Cao M, Jia W, Huang C, Xiao X: Gene expression analyses of $Z m P t i 1$, encoding a maize Pti-like kinase, suggest a role in stress signaling. Plant Sci 2006, 171:99-105.

10. Wang C, Wang X: A novel phospholipase D of Arabidopsis that is activated by oleic acid and associated with the plasma membrane. Plant Physiol 2001, 127:1102-1112.

11. Shirasu K, Schulze-Lefert P: Complex formation, promiscuity and multifunctionality: protein interactions in disease-resistance pathways. Trends Plant Sci 2003, 8:252-258.

12. Hudgins JW, Franceschi VR: Methyl jasmonate-induced ethylene production is responsible for conifer phloem defense responses and reprogramming of stem cambial zone for traumatic resin duct formation. Plant Physiol 2004, 35:2134-2149.

13. Llorente F, Alonso-Blanco C, Sanchez-Rodriguez C, Jorda L, Molin A: ERECTA receptor-like kinase and heterotrimeric $G$ protein from Arabidopsis are required for resistance to the necrotrophic fungus Plectosphaerella cucumerina. Plant J 2005, 43:165-180.

14. Langlois-Meurinne M, Gachon CMM, Saindrenan P: Pathogen-responsive expression of glycosyltransferase genes UGT73B3 and UGT73B5 is necessary for resistance to Pseudomonas syringae $p v$ tomato in Arabidopsis. Plant Physiol 2005, 139:1890-1901.

15. Bohm PAF, Zanardo FML, Ferrarese MLL, Ferrarese-Filho O: Peroxidase activity and lignification in soybean root growth-inhibition by juglone. Biologia Plantarum 2006, 50:315-317

16. Schwachtje J, Minchin PEH, Jahnke S, van Dongen JT, Schittko U, Baldwin IT: SNF1-related kinases allow plants to tolerate herbivory by allocating carbon to roots. Proc Natl Acad Sci USA 2006, 103:12935-12940.

17. Chen J, Zhang W, Song F, Zhen Z: Phospholipase C/diacylglycerol kinase-mediated signalling is required for benzothiadiazole-induced oxidative burst and hypersensitive cell death in rice suspensioncultured cells. Protoplasma 2007, 230:13-21

18. Ramina A, Chang C, Giovannoni J, Klee H, Perata P, Woltering E: Advances in plant ethylene research. In Proceedings of the 7th International Symposium on the Plant Hormone Ethylene 2007:105-107.

19. Franssen HJ, Bisseling T: Peptide signaling in plants. Proc Natl Acad SCi USA 2001, 98:12855-12856.

20. Cheng WH, Endo A, Zhou L, Penney J, Chen HC, Arroyo A, Leon P, Nambara E, Asami T, Seo M, Koshiba T, Sheen J: A unique short-chain dehydrogenase/reductase in Arabidopsis glucose signaling and abscisic acid biosynthesis and functions. Plant Cell 2002, 14:2723-2743.

21. Kerk D, Bulgrien J, W Smith D, Gribskov M: Arabidopsis proteins containing similarity to the universal stress protein domain of bacteria. Plant Physiol 2003, 131:1209-1219.

22. Ko CB, Woo YM, Lee DJ, Lee MC, Kim CS: Enhanced tolerance to heat stress in transgenic plants expressing the GASA4 gene. Plant Physiol Biochem 2007, 45:722-728.

23. Serrato AJ, Pe'rez-Ruiz JM, Spûnola MC, Cejudo FJ: A novel NADPH thioredoxin reductase, localized in the chloroplast, which deficiency causes hypersensitivity to abiotic stress in Arabidopsis thaliana. J Biol Chem 2004, 15:43821-3827.

24. Hondorp ER, Matthews RG: Oxidative stress inactivates cobalaminindependent methionine synthase (MetE) in Escherichia coli. PLOS BiO 2004, 2:1738-1753.
25. Zhu C, Gan L, Shen Z, Xia K: Interaction between jasmonates and ethylene in the regulation of root hair development in Arabidopsis. $J$ Exp Bot 2006, 57:1299-1308.

26. Bork P, Hofmann K, Bucher P, Neuwald AF, Altschul SF, Koonin EV: A superfamily of conserved domains in DNA damage-responsivecell cycle checkpoint proteins. FASEB J 1997, 11:68-76

27. Ishigawa A: Tetrapyrole metabolism is involved in lesion formation, cell death, in the Arabidopsis lesion initiation 1 mutant. Biosci Biotech Biochem 2005, 69:1929-1934.

28. Liu Y, Schiff M, Serino G, Deng XW, Dinesh-Kumar SP: Role of SCF ubiquitin-ligase and the COP9 signalosome in the $\mathrm{N}$ gene-mediated resistance response to Tobacco mosaic virus. Plant Cell 2002, 14:1483-1496.

29. Ren C, J Pan J, Peng W, Genschik P, Hobbie L, Hellmann H, Estelle M, Gao B, Peng J, Sun C, Xie D: Cullin 1 reveal its essential role in jasmonate response. Plant J 2005, 42:514-524.

30. Stone SL, Williams LA, Farmer LM, Richard D, Vierstra RD, Callis J: KEEP ON GOING, a RING E3 ligase essential for Arabidopsis growth and development, is involved in Abscisic Acid signaling. Plant Cell 2006, 18:3415-3428.

31. Kawasaki T, Nam J, Boyes DC, Holt BF III, Hubert DA, Wiig A: A duplicated pair of Arabidopsis RING-finger E3 ligases contribute to the RPM1- and RPS2-mediated hypersensitive response. Plant J 2005, 44:258-270.

32. Taupp DE, Nimtz M, Berger RG, Zorn H: Stress response of Nidula niveotomentosa to UV-A light. Mycologia 2008, 100:529-538.

33. Serrato AJ, Pe'rez-Ruiz JM, Spûnola MC, Cejudo FJ: A novel NADPH thioredoxin reductase, localized in the chloroplast, which deficiency causes hypersensitivity to abiotic stress in Arabidopsis thaliana. J Biol Chem 2004, 15:43821-3827.

34. Heinemann IU, Jahn M, Jahn D: The biochemistry of heme biosynthesis. Arch Biochem Biophys 2008, 474:238-251.

35. Navarro L, Zipfel C, Rowland W, Keller I, Robatzek S, Boller T, Jonathan DG, Jones JDC: The transitional innate immune response to flg22.interplay with Avr gene-dependent defense response and bacterial pathogenesis. Plant Physiol 2004, 135:1113-1128.

36. Llorente F, Alonso-Blanco C, Sanchez-Rodriguez C, Jorda L, Molin A: ERECTA receptor-like kinase and heterotrimeric $G$ protein from Arabidopsis are required for resistance to the necrotrophic fungus Plectosphaerella cucumerina. Plant J 2005, 43:165-180

37. Galon Y, Nave R, Boyce JM, Nachmias D, Knight MR, Fromm H: Calmodulin-binding transcription activator (CAMTA) 3 mediates biotic defense responses in Arabidopsis. FEBS Lett 2008, 582:943-948.

38. Kim CY, Liu Y, Thorne ET, Yang H, Fukushige H, Gassmann W, Hildebrand D, Sharp RE, Zhang S: Activation of a stress responsive mitogenactivated protein kinase cascade induces the biosynthesis of ethylene in plants. Plant Cell 2003, 15:2707-2718.

39. Bashir T, Dorrello NV, Amador V, Guardavaccaro D, Pagano M: Control of the SCF (Skp2-Cks1) ubiquitin ligase by the APC/C (Cdh1) ubiquitin ligase. Nature 2004, 428:190-193.

40. Havens CG, Ho A, Yoshioka N, Dowdy SF: Regulation of late G1/S phase transition and APC Cdh1 by reactive oxygen species. Mol Cell Bio/ 2006, 26:4701-4711

41. Drexler HCA: Programmed cell death and the proteasome. Apoptosis 1998, 3:1-7.

42. Smith CM, Rodriguez-Buey M, Karlsson J, Campbell MM: The response of the poplar transcriptome to wounding and subsequent infection by a viral pathogen. New Phytolo 2004, 164:123-136.

43. Dharmasiri S, Estelle M: The role of regulated protein degradation in auxin response. Plant Mol Biol 2002, 49:401-409.

44. Weijers D, Benkova E, Jäger KE, Schlereth A, Hamann T, Kientz M, Wilmoth JC, Reed JW, Jürgens G: Developmental specificity of auxin response by pairs of ARF and Aux/IAA transcriptional regulators. EMBO J 2005, 24:1874-1885

45. Davies KJ: Degradation of oxidized proteins by the $20 \mathrm{~S}$ proteasome. Biochimie 2003, 83:301-310.

46. Bader N, Grune T: Protein oxidation and proteolysis. Biol Chem 2006 387:1351-1355.

47. Hofius D, Tsitsigiannis DI, Jones JDG, Mundy J: Inducible cell death in plant immunity. Seminars in Cancer Bioliology 2007, 17:166-187.

48. Wycoff KL, Powel1 PA, Conzales RA, Corbin DR, Lamb C, Dixon RA: Stress activation of a bean hydroxyproline-rich glycoprotein promoter is 
superimposed on a pattern of tissue-specific developmental expression. Plant Physiol 1995, 109:41-52.

49. Chen K, Du L, Chen Z: Sensitization of defense responses and activation of programmed cell death by a pathogen-induced receptor-like protein kinase in Arabidopsis. Plant Mol Biol 2003, 53:61-74.

50. Van der Biezen EA, Jones JD: Plant disease-resistance proteins and the gene-for-gene concept. Trends Biochem Sci 1998, 23:454-456.

51. Nurnberger T, Brunner F, Kemmerling B, Piater L: Innate immunity in plants and animals: striking similarities and obvious differences. Immunology Rev 2004, 198:249-266.

52. Gelli A, Higgins VJ, Blumwald E: Activation of plant plasma membrane Ca2+-permeable channels by race-specific fungal elicitors. Plant Physiol 1997, 113:269-279.

53. Zimmermann S, Nurnberger T, Frachisse JM, Wirtz W, Guern J, Hedrich R: Receptor-mediated activation of a plant $\mathrm{Ca}^{2+}{ }^{2+}$ permeable ion channel involved in pathogen defense. Proc Natl Acad Sci USA 1997, 94:2751-2755.

54. Balague C, Lin B, Alcon C, Flottes G, Malmstrom S, Kohler C: HLM1, an essential signaling component in the hypersensitive response, is a member of the cyclic nucleotide-gated channel ion channel family. Plant Cell 2003, 15:365-379.

55. Grant M, Brown I, Adams S, Knight M, Ainslie A, Mansfield J: The RPM1 plant disease resistance gene facilitates a rapid and sustained increase in cytosolic calcium that is necessary for the oxidative burst and hypersensitive cell death. Plant J 2000, 23:441-450.

56. Torres MA, Jones JD, Dangl JL: Reactive oxygen species signaling in response to pathogens. Plant Physio/ 2006, 141:373-378.

57. Arner ES, Holmgren A: Physiological functions of thioredoxin and thioredoxin reductase. Euro J Biochem 2000, 267:6102-6109.

58. Laloi C, Rayapuram N, Chartier Y, Grienenberger JM, Bonnard G, Meyer Y: Identification and characterization of a mitochondrial thioredoxin system in plants. Proc Natl Acad Sci USA 2001, 98:4144-14149.

59. Reichheld JP, Khafif M, Riondet C, Michel Droux M, Bonnard G, Meyer Y: Inactivation of thioredoxin reductases reveals a complex interplay between thioredoxin and glutathione pathways in Arabidopsis development. Plant Cell 2007, 19:1851-1865.

60. Zhang J, Kirkham MB: Drought-stress-induced changes in activities of superoxide dismutase, catalase and peroxidase in wheat species. Plant Cell Physiol 1994, 35:785-791

61. Yoshimura Y, Ishikawa T, Shigeoka S: Expression of spinach ascorbate peroxidase isoenzymes in response to oxidative stresses. Plant Physiol 2000, 123:223-234.

62. Hiraga S, Yamamoto K, Ito H, Sasaki K, Matsui H, Honma M, Nagamura Y, Sasaki T, Ohashi Y: Diverse expression profiles of 21 rice peroxidase genes. FEBS Lett 2001, 471:245-250.

63. Tabuchi A, Matsumoto H: Changes in cell-wall properties of wheat (Triticum aestivum) roots during aluminum-induced growth inhibition. Physiol Plantarum 2001, 112:353-358.

64. Kawakami S, Matsumoto Y, Matsunaga A, Mayama S, Mizuno M: Molecular cloning of ascorbate peroxidase in potato tubers and its response during storage at low temperature. Plant Sci 2002, 163:829-836.

65. Panchuk II, Volkov RA, Schoffl F: Heat stress- and heat shock transcription factor-dependent expression and activity of ascorbate peroxidase in Arabidopsis. Plant Physiol 2002, 129:1-16.

66. Shirasu K, Schulze-Lefert P: Complex formation, promiscuity and multifunctionality: protein interactions in disease-resistance pathways. Trends Plant Sci 2003, 8:252-258.

67. Liu Y, Schiff M, Serino G, Deng XW, Dinesh-Kumar SP: Role of SCF ubiquitin-ligase and the COP9 signalosome in the $\mathrm{N}$ gene-mediated resistance response to Tobacco mosaic virus. Plant Cell 2002, 14:1483-1496

68. Kawasaki T, Nam J, Boyes DC, Holt BF III, Hubert DA, Wiig A: A duplicated pair of Arabidopsis RING-finger E3 ligases contribute to the RPM1- and RPS2-mediated hypersensitive response. Plant J 2005, 44:258-270.

69. Lin SS, Martin R, Mongrand S, Vandenabeels S, Chen KC, Jang IC, Chua NH: RING1 E3 ligase localizes to plasma membrane lipid raft to trigger FB1induced programmed cell death in Arabidopsis. Plant $J$ 2008, 56:550-561.

70. Ren C, J Pan J, Peng W, Genschik P, Hobbie L, Hellmann H, Estelle M, Gao B, Peng J, Sun C, Xie D: Cullin1 reveal its essential role in jasmonate response. Plant J 2005, 42:514-524.
71. Drew MC, He CJ, Morgan PW: Programmed cell death and aerenchyma formation in roots. Trends Plant Sci 2000, 5:123-127.

72. Ohtsubo N, Mitsuhara I, Koga M, Seo S, Ohashi Y: Ethylene promotes the necrotic lesion formation and basic PR gene expression in TMVinfected tobacco. Plant Cell Physiol 1999, 40:808-817.

73. Ciardi JA, Tieman DM, Lund ST, Jones JB, Stall RE, Klee HJ: Response to Xanthomonas campestris pv. vesicatoria in tomato involves regulation of ethylene receptor gene expression. Plant Physiol 2000, 123:81-92.

74. Danon A, Miersch O, Felix G, Camp RG, Apel K: Concurrent activation of cell death-regulating signaling pathways by singlet oxygen in Arabidopsis thaliana. Plant J 2005, 41:68-80.

75. Andi S, Taguchi F, Toyoda K, Shiraishi T, Ichinose Y: Effect of Methyl Jasmonate on Harpin-Induced Hypersensitive Cell Death, Generation of Hydrogen Peroxide and Expression of PAL mRNA in Tobacco Suspension Cultured BY-2 Cells. Plant Cell Physiol 2001, 42:446-449.

76. Desikan R, Mackerness SA-H, Hancock JT, Neill SJ: Regulation of the Arabidopsis transcriptome by oxidative stress. Plant Physio/ 2001, 127:159-172.

77. Levine A, Tenhaken $\mathrm{R}$, Dixon $\mathrm{R}$, Lamb C: $\mathrm{H}_{2} \mathrm{O}_{2}$ from the oxidative burst orchestrates the plant hypersensitive disease resistance response. Cell 1994, 79:583-593.

78. Desikan R, Reynolds A, Hancock JT, Neill SJ: Hairpin and hydrogen peroxide both initiate programmed cell death but have differential effects on gene expression in Arabidopsis suspension cultures. Biochemical J 1998a, 330:115-120.

79. Mittler R, Herr EH, Orvar BL, van Camp W, Willekens H, Inze D: Transgenic tobacco plants with reduced capability to detoxify reactive oxygen intermediates are hyper-responsive to pathogen infection. Proc Natl Acad SciUSA 1999, 96:14165-14170.

80. Solomon M, Belenghi B, Delledonne M, Menachem E, Levine M: The involvement of cysteine proteases and protease inhibitor genes in the regulation of programmed cell death in plants. Plant Cell 1999, 11:431-443

81. Kovtun Y, Chiu WL, G Tena G, Sheen J: Functional analysis of oxidative stress-activated mitogen-activated protein kinase cascade in plants. Proc Natl Acad Sci USA 2000, 97:2940-2945.

82. Pearce G, Strydom D, Johnson S, Ryan CA: A Polypeptide from Tomato Leaves Induces Wound-Inducible Proteinase Inhibitor Proteins. Science 1991, 253:895-898.

83. Sommer T, Chambers AA, Eberle J, Lauter FR, Russo VEA: Fast lightregulated genes of Neurospora crassa. Nucleic Acids Res 1989, 14:5713-572.

84. Baima S, Macino G, Morelli G: Photoregulation of the albino-3 gene in Neurospora crassa. J Photochem Photobiol 1991, 11:107-115.

85. Linden H, Ballario P, Macino G: Blue Light Regulation in Neurospora crassa. Fungal Genet Biol 1997, 22:141-150

86. Mullineaux P, Ball L, Escobar C, Karpinski B, Creissen G, Karpinski S: Are diverse signaling pathways integrated in the regulation of Arabidopsis antioxidant defence gene expression in response to excess excitation energy. Phil Trans R SOC B 2000, 355:1531-1540.

87. Aneeta SMN, Tuteja N, Kumar S: Salinity- and ABA induced up-regulation and light-mediated modulation of mRNA encoding glycine-rich RNAbinding protein from Sorghum bicolor. Biochem Biophys Res Commun 2002, 296:1063-1068.

88. Karpinski S, Gabrys H, Mateo A, Karpinska B, Mullineaux PM: Light perception in plant disease defence signalling. Curr Opin Plant Biol 2003, 6:390-396

89. Soitamo AJ, Piippo M, Allahverdiyeva Y, Battchikova N, Aro EM: Light has a specific role in modulating Arabidopsis gene expression at low temperature. BMC Plant Biol 2007, 8:13-25.

90. Baum G, Long JC, Jenkins Gl, Trewavas AJ: Stimulation of the blue light phototropic receptor NPH1 causes a transient increase in cytoplasmic $\mathrm{Ca}^{2+}$. Proc Natl Acad Sci USA 1999, 96:554-559.

91. Babourina $\mathrm{O}$, Newman I, Shabala S: Blue light-induced kinetics of $\mathrm{H}_{-}$and Ca2_fluxes in etiolated wild-type and phototropin-mutant Arabidopsis seedlings. Proc Natl Acad Sci USA 2002, 99:2433-2438,

92. Harada A, Sakai T, Okada K: phot1 and phot2 mediate blue light-induced transient increases in cytosolic Ca21 differently in Arabidopsis leaves. Proc Natl Acad Sci USA 2003, 100:8583-8588.

93. Stoelzle S, Kagawa T, Wada M, Hedrich R, Dietrich P: Blue light activates calcium-permeable channels in Arabidopsis mesophyll cells via the 
phototropin signaling pathway. Proc Natl Acad Sci USA 2003, 100:1456-1461.

94. Shinkle JR, Jones RL: Inhibition of stem elongation in Cucumis seedlings by blue light requires calcium. Plant Physiol 1988, 86:960-966.

95. Folta KM, Lieg EJ, Durham T, Spalding EP: Primary inhibition of hypocotyl growth and phototropism depend differently on phototropinmediated increases in cytoplasmic calcium induced by blue light. Plant Physiol 2003, 133:1464-1470.

96. Kinoshita T, Shimazaki Kl: Blue light activates the plasma membrane $\mathrm{H}$ ATPase by phosphorylation of the C-terminus in stomatal guard cells. EMBO J 1999, 18:5548-5558.

97. Kinoshita T, Doi M, Suetsugu N, Kagawa T, Wada M, Shimazaki Kl: phot1 and phot 2 mediate blue light regulation of stomatal opening. Nature 2001, 414:656-660.

98. Schroeder JI, Allen GJ, Hugouvieux V, Kwak JM, Waner D: Guard cell signal transduction. Ann Rev Plant Physiol Plant Mol Biol 2001, 52:627-658.

99. Pedmale UV, Liscum E: Regulation of phototropic signaling in Arabidopsis via phosphorylation state changes in the phototropin 1interacting protein NPH3. J Biol Chem 2007, 282:19992-20001.

100. Sakai T, Kagawa T, Kasahara M, Swartz TE, Christie JM, Briggs WR, Wada M, Okada K: Arabidopsis nph1 and npl1: blue light receptors that mediate both phototropism and chloroplast relocation. Proc Natl Acad Sci USA 2001, 98:6969-6974

101. Sakai T, Wada T, Ishiguro S, Okada K: RPT2, A signal transducer of the phototropic response in Arabidopsis. Plant Cell 2000, 12:225-236.

102. Spalding EP: lon channels and the transduction of light signals. Plant Cell Environ 2000, 23:665-674.

103. Kagawa T, Wada M: Blue light induced chloroplast relocation in Arabidopsis thaliana as analyzed by microbeam irradiation. Plant Cell Physiol 2000, 41:84-93.

104. Jiao Y, Ma L, Strickland E, Deng XW: Conservation and divergence of light-regulated genome expression patterns during seedling development in rice and Arabidopsis. Plant Cell 2005, 17:3239-3256.

105. Ma L, Gao Y, Qu LJ, Chen Z, Li J, Zhao H, Deng XW: Genomic evidence for COP1 as a repressor of light-regulated gene expression and development in Arabidopsis. Plant Cell 2002, 14:2383-2398.

106. Ma L, Li J, Qu L, Hager J, Chen Z, Zhao H, Deng XW: Light control of Arabidopsis development entails coordinated regulation of genome expression and cellular pathways. Plant Cell 2001, 13:2589-2607.

107. Jiao Y, Yang H, Ma L, Sun N, Yu H, Liu T, Gao Y, Gu H, Chen Z, Wada M, Gerstein M, Zhao H, Qu LJ, Deng XW: A genome-wide analysis of bluelight regulation of Arabidopsis transcription factor gene expression during seedling development. Plant Physiol 2003, 133:1480-1493.

108. Paul ND, Roberts MR: Seduced by the dark side: integrating molecular and ecological perspectives on the influence of light on plant defence against pests and pathogens. New Phytolo 2006, 170:677-699.

109. Cheung MY, Zeng NY, Tong SW, Francisca Li WY, Xue Y, Zhao KJ, Wang C, Zhang Q, Fu Y, Sun Z, Sun SSM, Lam HM: Constitutive expression of a rice GTPase-activating protein induces defense responses. New Phytolo 2008, 179:530-545.

110. Ono E, Wong HL, Kawasaki T, Hasegawa M: Essential role of the small GTPase Rac in disease resistance of rice. Proc Natl Acad Sci USA 2001, 98:759-764

111. Guo A, Reimers PJ, Leach JE: Effect of light on incompatible interactions between Xanthomonas oryzae pv oryzae and rice. Physiological and Molecular Plant Pathol 1993, 42:413-425.

112. Mateo A, Mühlenbock P, Rustérucci C, Chang CC-C, Miszalski Z, Karpinska B, Parker JE, Mullineaux PM, Karpinski S: LESION SIMULATING DISEASE 1 is required for acclimation to conditions that promote excess excitation energy. Plant Physiol 2004, 136:2818-2830.

113. Zeier J, Pink B, Mueller MJ, Berger S: Light conditions influence specific defence responses in incompatible plant-pathogen interactions: uncoupling systemic resistance from salicylic acid and PR-1 accumulation. Planta 2004, 219:673-683.

114. Peever TL, Higgins VJ: Electrolyte leakage, lipoxygenase, and lipidperoxidation induced in tomato leaf tissue by specific and nonspecific elicitors from Cladosporium-fulvum. Plant Physiol 1989, 90:867-875.

115. Moussatos V, Witsenboer H, Hille J, Gilchrist D: Behaviour of the disease resistance gene Asc in protoplasts of Lycopersicon esculentum mill. Physiological and Molecular Plant Pathol 1993, 43:255-263.

116. Asai T, Stone JM, Heard JE, Kovtun Y, Yorgey P, Sheen J, Ausubel FM: Fumonisin B1-induced cell death in Arabidopsis protoplasts requires jasmonate-, ethylene-, and salicylate-dependent signaling pathways. Plant Cell 2000, 12:1823-1835.

117. Yang M, Wardzala E, Johal GS, Gray J: The wound-inducible LIs1 gene from maize is an orthologue of the Arabidopsis Acd1 gene, and the LLS1 protein is present in non-photosynthetic tissues. Plant Mol Biol 2004, 54:175-191.

118. Bechtold U, Karpinski S, Mullineaux P: The influence of the light environment and photosynthesis on oxidative signalling responses in plant-biotrophic pathogen interactions. Plant Cell Env 2005, 28:1046-1055

119. Chandra-Shekara AC, Gupte M, Navarre D, Raina S, Raina R, Klessig D: Light-dependent hypersensitive response and resistance signalling against Turnip Crinkle Virus in Arabidopsis. Plant J 2006, 45:320-334.

120. Brunner AM, Yakovlev IA, Strauss SH: Validating internal controls for quantitative plant gene expression studies. BMC Plant Biol 2004, 4:14-18.

doi: 10.1186/1471-2229-10-11

Cite this article as: Moehninsi et al., Comparative transcriptional profilingbased identification of raphanusanin-inducible genes BMC Plant Biology 2010, 10:11

\section{Submit your next manuscript to BioMed Centra and take full advantage of:}

- Convenient online submission

- Thorough peer review

- No space constraints or color figure charges

- Immediate publication on acceptance

- Inclusion in PubMed, CAS, Scopus and Google Scholar

- Research which is freely available for redistribution
C BioMed Central 